\author{
ZVI GRILICHES
}

Harvard University

\title{
Patents: Recent Trends and Puzzles
}

AMONG THE MANY explanations for the worldwide productivity slowdown in the 1970s, the exhaustion of inventive and technological opportunities remains a major suspect. This suspicion is fed by one of the more visible statistical facts: the total number of patents granted peaked in the United States about 1970 and then declined through most of the decade (figure 1). Similar trends can also be observed in patenting worldwide, except in Japan. ${ }^{1}$ These same kind of data also fed the idea that the United States had lost its competitive inventive edge. Patents granted to U.S. corporations peaked in the mid-1960s and have not really recovered since (figure 2). A related notion is diminishing returns to inventive activity, to investments in research and development. In figure 2 one notices the much more rapid rate of growth in national $R \& D$ expenditures than in total patenting and the implicit suggestion of diminishing returns.

In what follows, I argue that one should not reach such conclusions without first examining the meaning and construction of patent data. Two points will be made: patents are not a constant-yardstick indicator of either inventive input or output; moreover, they are "produced" by a governmental agency, the U.S. Patent Office, that goes through its own budgetary and inefficiency cycle. These considerations effectively dispose of the appearance of absolute declines in such data, but leave

I am indebted to Bronwyn $\mathrm{H}$. Hall for some of the data presented here and for access to her unpublished paper, "Fishing Out or Crowding Out: An Analysis of the Recent Decline in U.S. Patenting," University of California at Berkeley, 1988. The research was supported by National Science Foundation grants PRA 85-12758 and SES 82-08006.

1. See Martin Neil Baily and Alok K. Chakrabarti, Innovation and the Productivity Crisis (Brookings 1988). See also Robert E. Evenson, "International Invention: Implications for Technology Market Analysis," in Zvi Griliches, ed., R\&D, Patents, and Productivity (University of Chicago Press, 1984), pp. 89-123; and A. Steven Englander, Robert E. Evenson, and Masaharu Hanazaki, "R\&D, Innovation, and the Total Factor Productivity Slowdown," OECD Economic Studies, no. 11 (Autumn 1988), pp. 7-42. 
Figure 1. U.S. Patent Applications and Grants, 1880-1987

Number (thousands)

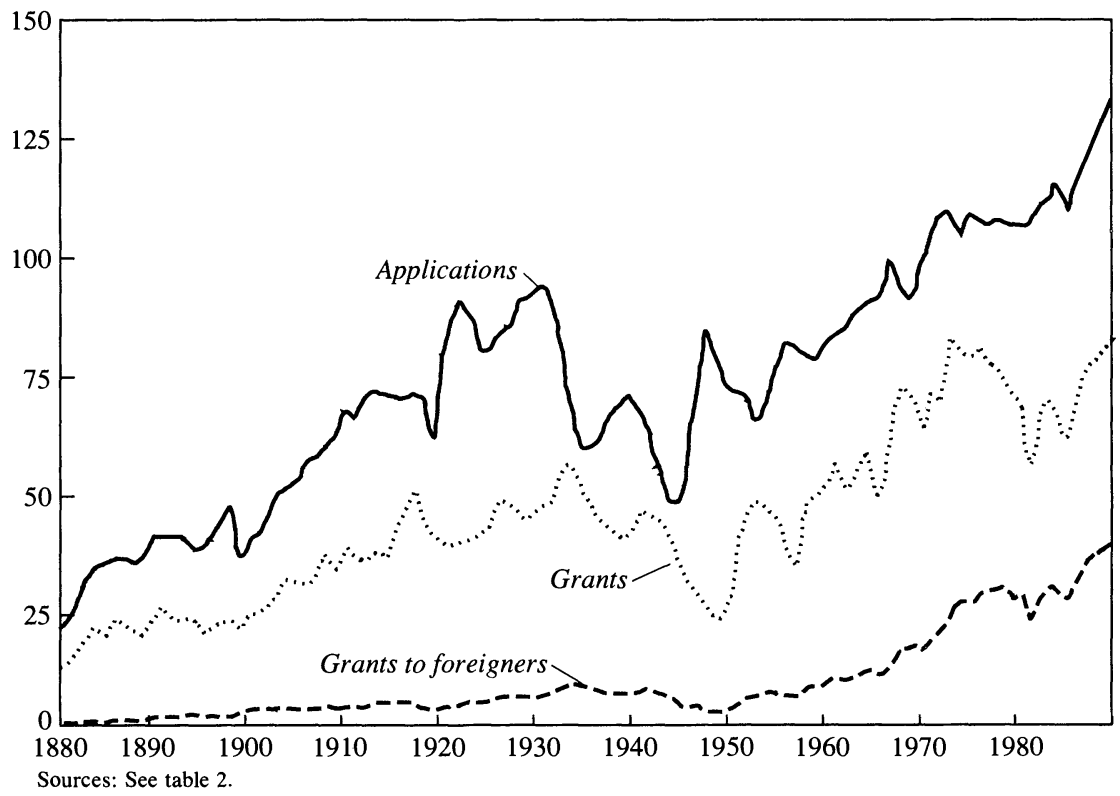

the longer-run puzzle of potential diminishing returns to $R \& D$. The paper closes with some comments on that theme.

\section{The Granting Process}

Figure 1 points out two important aspects of the data: the trends in patent grants do not always follow those of patent applications, and cycles have occurred in earlier periods. An application for a patent is filed when, presumably, the expected value of receiving the patent exceeds the cost of applying for it. The expected value of a patent equals the probability that it will be granted, times the expected economic value of the rights associated with the particular patented item or idea, minus the potentially negative effects arising from its disclosure. A patent is granted if it passes certain minimal standards of novelty and potential utility. These standards can change over time, both because of changes in the perception of what is an innovation and because of changing 
Figure 2. U.S. Domestic Patent Applications, Grants to U.S. Corporations, and Company-Financed R\&D, 1953-87

Log scale

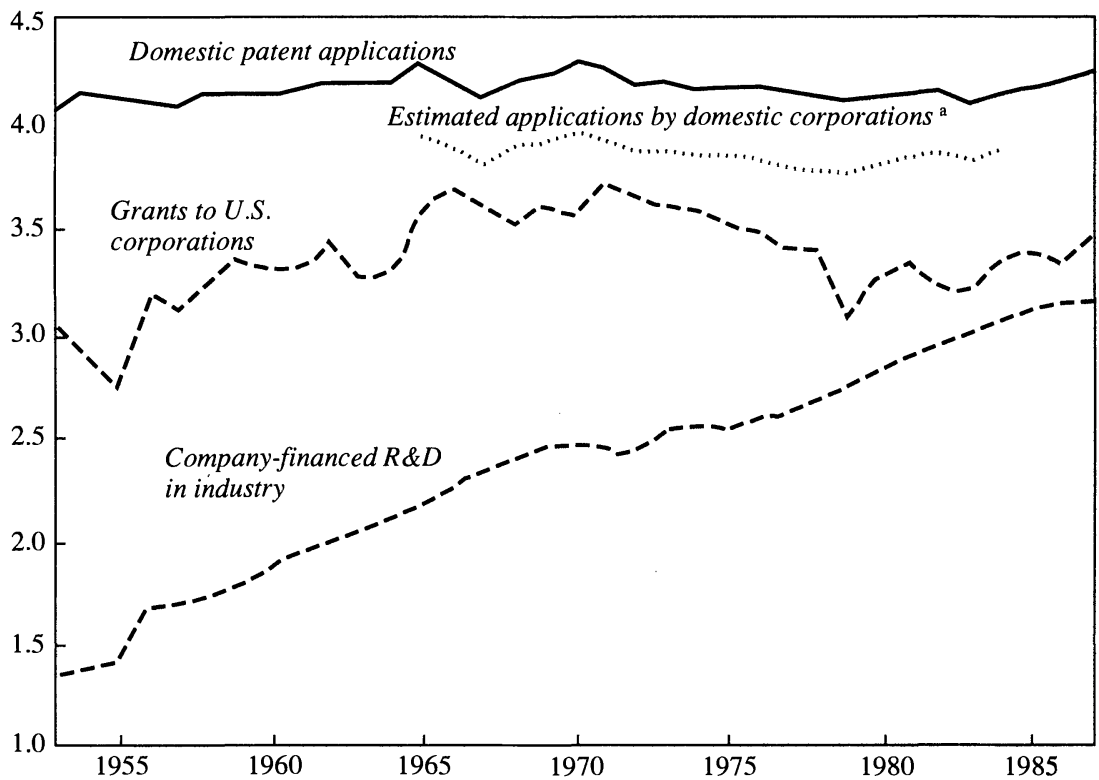

Sources: See tables 2, 4, and 5 .

a. Corporate grants by date applied for, inflated by $1.00 / 0.65$, the average application success rate.

application pressure on a relatively fixed number of Patent Office workers. (It might be useful here to think of an analogy to articles and journals, the publication rate being limited both by the available number of pages and by the limited number of referees.) Moreover, a change in the resources of the Patent Office or in its efficiency will introduce changes in the lag structure of grants behind applications and may produce a misleading picture of the underlying trends. In particular, the decline in the number of patents granted in the 1970s is almost entirely an artifact induced by fluctuations in the Patent Office, culminating in the sharp dip in 1979 due to the lack of budget for printing the approved patents. ${ }^{2}$

2. The effect of changes in bureaucratic procedures on shorter-run aspects of these data is discussed by Brunk and Demack, who point out that for some time after 1968 the Patent Office was issuing a fixed number of patents each week, with this number changing sporadically as the backlog vari $\rightarrow$ G. G. Brunk and C. Demack, "Short-run Trends in U.S. Patent Activity,"' Scientometrics, vol. 12, nos. 1-2 (1987), pp. 111-33. 
Figure 3. Actual and Predicted Patent Grants and Number of Patent Examiners, 1947-87

Examiners

Patents

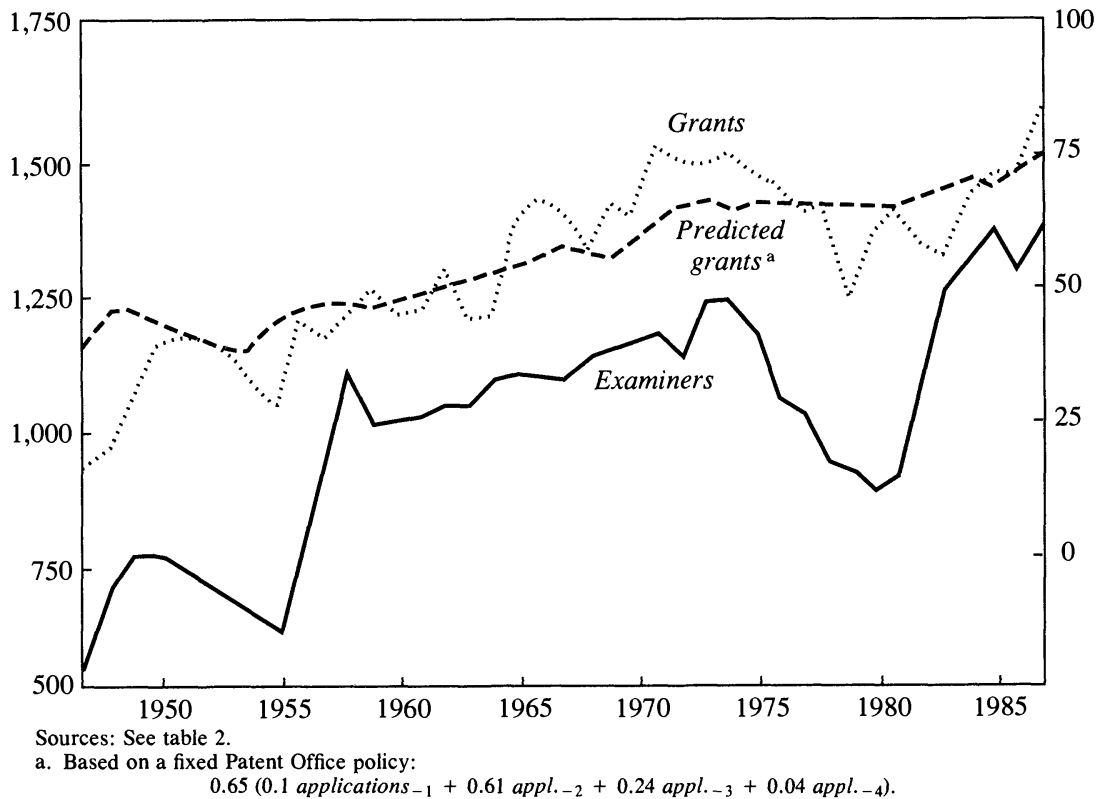

The last point can be made in several ways. Perhaps the simplest way is shown in figure 3, which plots the number of grants that would be predicted by a constant Patent Office policy and performance, that is, a 65 percent approval rate and a constant lag structure. The graph of such a "prediction" is essentially flat throughout the 1970s, reflecting the rough constancy of total applications during this period. Table 1 shows, at the same time, that the lag structure of the granting process changed markedly during the last twenty years. In the late 1960s it took more than three years for half the eventual grants to be issued. Beginning in 1971, a campaign to reduce these lags and eliminate the accumulating backlog brought down the fraction taking more than three years to about 10 percent by the late 1970 s. But by the early 1980 s the Patent Office ran into another budgetary crisis, and the backlog began to grow again.

Another way of looking at the granting process is by way of an estimated Patent Office production function, which regards the number of patents granted as a function of two major inputs: the internal resources available to it, the average number of patent examiners over the previous 
Table 1. Distribution of Patents Granted by Year of Application, 1966-82, and Time to Year of Grant

\begin{tabular}{|c|c|c|c|c|c|c|c|}
\hline \multirow{3}{*}{$\begin{array}{c}\text { Year of } \\
\text { application }\end{array}$} & \multicolumn{7}{|c|}{ Percent of patents granted } \\
\hline & \multicolumn{6}{|c|}{ Years after application } & \multirow{2}{*}{$\begin{array}{c}\text { Within } \\
\text { three years } \\
\text { of } \\
\text { application }\end{array}$} \\
\hline & 0 & 1 & 2 & 3 & 4 & $5+$ & \\
\hline 1966 & 1 & 13 & 36 & 35 & 12 & 3 & 50 \\
\hline 1967 & 1 & 13 & 43 & 33 & 8 & 2 & 57 \\
\hline 1968 & 0 & 12 & 44 & 36 & 6 & 2 & 56 \\
\hline 1969 & 0 & 11 & 66 & 20 & 2 & 1 & 77 \\
\hline 1970 & 0 & 18 & 62 & 17 & 2 & 1 & 80 \\
\hline 1971 & 0 & 17 & 61 & 18 & 2 & 2 & 78 \\
\hline 1972 & 0 & 28 & 57 & 11 & 2 & 2 & 85 \\
\hline 1973 & 0 & 37 & 50 & 10 & 2 & 1 & 87 \\
\hline 1974 & 1 & 42 & 48 & 6 & 2 & 1 & 91 \\
\hline 1975 & 1 & 42 & 46 & 8 & 1 & 2 & 89 \\
\hline 1976 & 2 & 42 & 47 & 6 & 2 & 2 & 91 \\
\hline 1977 & 1 & 42 & 41 & 12 & 2 & 2 & 84 \\
\hline 1978 & 1 & 24 & 57 & 15 & 2 & 1 & 82 \\
\hline 1979 & 0 & 22 & 60 & 15 & 2 & 1 & 82 \\
\hline 1980 & 0 & 22 & 53 & 20 & 3 & 2 & 75 \\
\hline $1981^{\mathrm{a}}$ & 0 & 17 & 50 & 27 & $\ldots$ & $\ldots$ & 67 \\
\hline $1982^{a}$ & 0 & 15 & 52 & $\ldots$ & $\ldots$ & $\ldots$ & 67 \\
\hline
\end{tabular}

Sources: For 1966-68 see special tabulation by the Office of Technology Assessment and Forecast (OTAF); 196970 based on a sample of 100,000 patents from the 1969-79 OTAF tape on patents granted; and 1971-82 based on the complete 1984 OTAF tape.

a. Estimated.

three years $(A V E X A M)$; and the "materials" it has to work with, lagged past applications (in the form of the PRGRNT variable). Table 2 shows several such regressions for 1924-87 and later periods (examiner data are not available before 1920). The chief determinant of the number of patents granted is the number of patent examiners employed by the Patent Office. Their estimated coefficient is approximately one. The supply of applications is important, but it works largely through the examiner variable. Examiners are employed, in part, in response to application pressure and the state of the accumulating backlog. There appears to have been a negative trend in the "efficiency" of patent examiners, perhaps because of the rising complexity of applications and the increasing size of the literature that needed to be searched. ${ }^{3}$ That

3. For evidence of rising complexity, see F. M. Scherer, Patents and the Corporation: A Report on Industrial Technology under Changing Public Policy, 2d ed. (Boston: James Galvin and Associates, 1959), p. 134. 
Table 2. The Patent Office Production Function, 1925-87

\begin{tabular}{|c|c|c|c|c|c|}
\hline \multirow[b]{3}{*}{ Variable } & \multicolumn{5}{|c|}{ Coefficients $^{\mathrm{a}}$} \\
\hline & \multicolumn{2}{|c|}{ Log total grants } & \multicolumn{3}{|c|}{ Log domestic grants } \\
\hline & $1925-87$ & $1945-87$ & & $1945-87$ & \\
\hline Log average examiner ${ }^{b}$ & $\begin{array}{c}0.916 \\
(0.145)\end{array}$ & $\begin{array}{c}0.879 \\
(0.129)\end{array}$ & $\begin{array}{c}0.938 \\
(0.153)\end{array}$ & $\begin{array}{c}0.957 \\
(0.146)\end{array}$ & $\begin{array}{c}0.899 \\
(0.130)\end{array}$ \\
\hline Log predicted grants ${ }^{\mathfrak{c}}$ & $\begin{array}{c}0.479 \\
(0.188)\end{array}$ & $\begin{array}{c}0.419 \\
(0.129)\end{array}$ & $\ldots$ & . . & $\cdots$ \\
\hline Time & $\begin{array}{r}-0.026 \\
(0.008)\end{array}$ & $\ldots$ & $\ldots$ & $\begin{array}{r}-0.010 \\
(0.003)\end{array}$ & $\ldots$ \\
\hline Time squared & $\begin{array}{c}0.00025 \\
(0.00010)\end{array}$ & $\ldots$ & $\ldots$ & $\ldots$ & $\ldots$ \\
\hline $\begin{array}{l}\text { Log domestic predicted } \\
\text { grants }\end{array}$ & $\ldots$ & $\ldots$ & $\begin{array}{c}0.625 \\
(0.325)\end{array}$ & $\begin{array}{c}0.400 \\
(0.301)\end{array}$ & $\begin{array}{c}0.333 \\
(0.311)\end{array}$ \\
\hline $\begin{array}{l}\text { Log foreign predicted } \\
\text { grants }\end{array}$ & $\ldots$ & $\ldots$ & $\begin{array}{r}-0.195 \\
(0.071)\end{array}$ & $\ldots$ & $\ldots$ \\
\hline $\begin{array}{l}\text { Logit foreign application } \\
\text { ratio }^{d}\end{array}$ & $\ldots$ & $\ldots$ & $\ldots$ & $\ldots$ & $\begin{array}{r}-0.102 \\
(0.031)\end{array}$ \\
\hline \multicolumn{6}{|l|}{ Summary statistics } \\
\hline $\bar{R}^{2}$ & 0.890 & 0.950 & 0.788 & 0.796 & 0.800 \\
\hline Standard error & 0.107 & 0.115 & 0.119 & 0.117 & 0.116 \\
\hline$A R(1)^{\mathrm{e}}$ & $\begin{array}{c}0.427 \\
(0.121)\end{array}$ & $\begin{array}{c}0.273 \\
(0.153)\end{array}$ & $\begin{array}{c}0.286 \\
(0.160)\end{array}$ & $\begin{array}{c}0.273 \\
(0.158)\end{array}$ & $\begin{array}{c}0.273 \\
(0.159)\end{array}$ \\
\hline
\end{tabular}

Sources: U.S. Bureau of the Census, Historical Statistics of the United States, Colonial Times to 1970, pt. 2 (Department of Commerce, 1975), chap. W; U.S. Patent and Trademark Office, Technology Assessment and Forecasts (Department of Commerce, March 1977), app. A; National Science Board, Science and Engineering Indicators, 1987, NSB 87-1 (Washington, 1987); and Patent and Trademark Office releases. Number of applications by residence of inventor for 1940-59, unpublished memorandum of P. F. Fredrico, Patent and Trademark Office, January 18, 1961; for 1960, Journal of the Patent Office Society, vol. 44 (February 1964), p. 168; for 1961-62, Commissioner of Patents and Trademarks, Annual Report, 1966, p. 26; for 1963-87, Patent and Trademark Office releases. Number of examiners, Bronwyn H. Hall, "Fishing Out or Crowding Out: An Analysis of the Recent Decline in U.S. Patenting," University of California at Berkeley, March 1988; private communication from Patent Office; and Patent and Trademark Office annual reports.

a. Numbers in parentheses are standard errors.

b. (examiners $-1+$ examiners $_{-2}+$ examiner $\left._{-3}\right) / 3$.

c. 0.65 (0.1 applications $-1+0.61$ appl. $-2+0.24$ appl $.-3+0.04$ appl. $\left._{-4}\right)$.

d. $\log \{$ for. appl./total appl. $) /[1$ - (for. appl./total appl. $)]\}$.

e. First order autoregressive serial correlation adjustment.

trend was largely over by 1960 . It changed sign in the mid-1970s and by itself was not statistically significant in the post-World War II period.

Similar conclusions can be reached by looking at figure 3, which focuses on the postwar period and plots the original data. What is clear from this figure is that the shorter-run fluctuations in the total number of patents granted are much more closely associated with the number of examiners than with the inflow of patent applications (" predicted grants" being just a scaled moving average of recent applications). It is also clear 
that the decline in patents granted in the 1970s came not from a decline in applications-they declined very little-but from the contraction in the resources of the Patent Office. Thus this particular indicator of technological decline was nothing more than a bureaucratic mirage!

The story for grants to domestic inventors, shown in columns 3-5 of table 2, is quite similar. Most of the variability in the number of grants is again attributable to the number of examiners. But there is also evidence of a significant negative effect of the rising number of foreign applications, represented in this table by the number of predicted grants to foreigners or the logit transformed ratio of foreign applications. Both versions of this variable show a crowding out of domestic patents by the rising tide of foreign applications and provide a substantive interpretation for the negative trend in this equation. But that does not solve all the mystery. For domestic patents a decline in applications also occurred in the 1970s that requires an interpretation of its own.

\section{Domestic Patenting and Inventive Activity}

Before looking at the determinants of domestic patenting and its interpretation as an indicator of inventive activity, I want to make a cautionary point. If one wants to explain technical change in the United States, using total factor productivity measures or related indexes, domestic patenting is not necessarily the relevant magnitude. Total patents may be a better measure of shifts in technology in the production possibilities frontiers. It does not matter where the invention came from. Foreign inventions should have a similar effect; thus for measures of technological opportunity available to the U.S. economy, total patents are probably the better index. The level of domestic patenting is more relevant for studies of competitiveness and for interpreting rates of return to domestic $\mathrm{R} \& \mathrm{D}$. Changes in measured productivity growth are also affected by changes in capacity utilization and so, also indirectly, by the competitiveness of the domestic industries. It is interesting, therefore, to know what happened to levels of inventive activity in the United States, but whether the data on patenting by U.S. residents can tell us this is uncertain.

Figure 4 plots the long-term data on domestic patent applications, real gross national product, and gross private domestic investment, all on a common log scale. (The domestic patent application numbers are 
Figure 4. U.S. Domestic Patent Applications, Real GNP, and Gross Private Domestic Investment, 1880-1987

Log scale

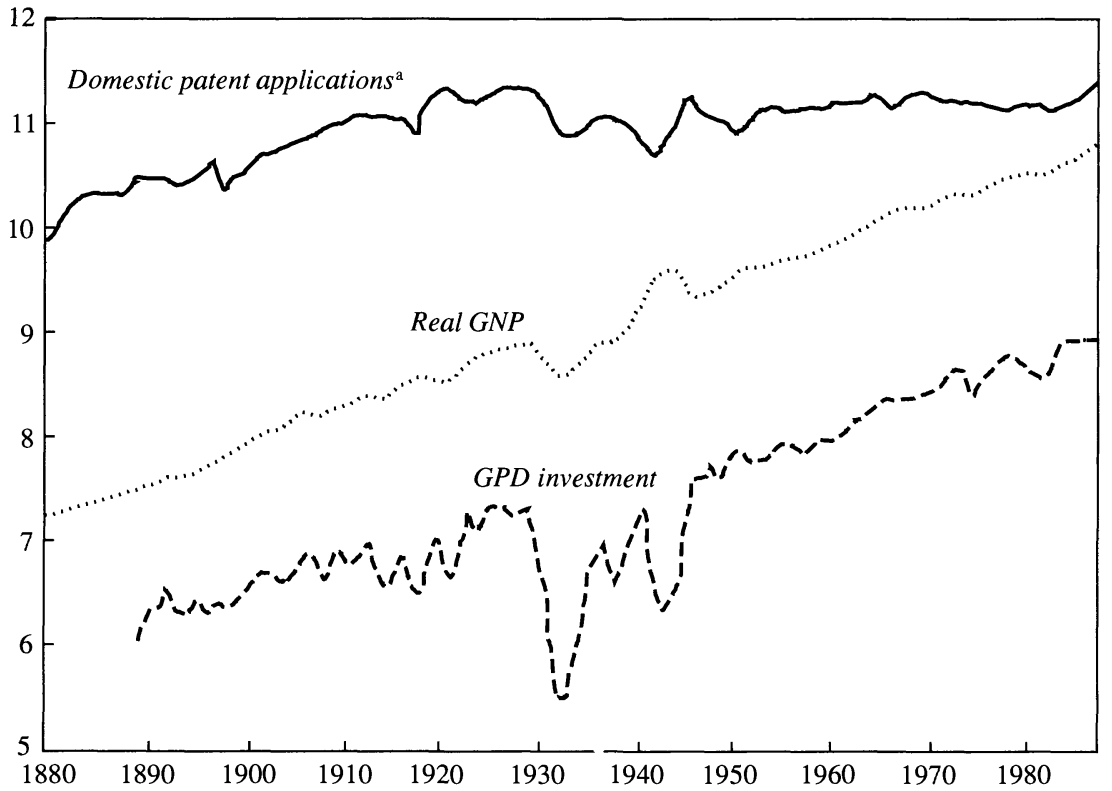

Sources: See tables 2 and 5.

a. Domestic applications are extrapolated back, before 1940 , by the number of total applications.

extrapolated backward, before 1940, by the number of total patent applications, foreign applications constituting less than 10 percent of the total at that time.) Several interesting facts stand out in this figure. After growing at roughly the same rate as real GNP in the late nineteenth and early twentieth century, domestic patent applications peaked in the late 1920s and have not achieved such levels again. After a severe decline during the Great Depression and the early war years and a brief postwar recovery, they stayed essentially flat throughout the postwar period, while both GNP and total and corporate R\&D expenditures were growing. These facts led Schmookler to claim that such data are not really comparable for the prewar and postwar periods. ${ }^{4} \mathrm{He}$ gave three reasons for the shortfall in the more recent period. First, the judicial and political climate changed in the late 1930s and became much more hostile to corporate patenting and the enforcement of patent rights, thereby

4. Jacob Schmookler, Invention and Economic Growth (Harvard University Press, 1966), pp. 28-30. 
reducing the value of applying for one. (This may have reversed itself in recent years.) Second, growing delays in processing patent applications at the Patent Office reduced the ultimate value of such protection. (The length of the delay went through several cycles, and its magnitude does not appear to be large enough to provide much of an explanation for the observed decline, as was seen in table 1.) Third, industries developed that relied less on patents and more on secrecy and on first-mover advantage, and many corporations realized they might be able to do without patenting. (Here too, as table 3 will show, the computable effects appear to be small.) What Schmookler did not mention explicitly was the rise in the real wage and hence the rise in the opportunity cost of dealing with the patent system. This rise in real wages contributed to the significant decline in the number of patents issued to "independent" inventors and probably also to a higher threshold of potential value for corporations before they would file an application. If that is true, then the relative stagnation of domestic applications in the postwar period does not preclude the possibility that real inventive activity and its output were rising at the same time. ${ }^{5}$

The number of patent applications (and grants) grew sharply and more or less steadily from 1880 to 1920 without the help of any formal or recorded $R \& D$ expenditures, and they grew very little during the $1950 \mathrm{~s}$ and 1960s, the period of most rapid growth in both total and corporate R\&D in U.S. industry. Thus such patent numbers should not be taken as a good, constant-yardstick, indicator of the output of R\&D unless one admits the possibility of sharply diminishing returns to such investments. That is the question I will keep coming back to in the rest of the paper.

\section{Domestic Patenting and Changes in the Industrial Mix}

Between 1955 and 1986 the number of domestic patent applications hovered around 64,000. It peaked in 1970 at about 72,000 , declined to a low of 61,000 in 1979, and then hit another low of 59,000 in 1983 before

5. The only indirect evidence on this point that I know of comes from Schankerman and Pakes's study of patent renewal data in Europe, which can be taken to show that the average value of a patent right rose between 1955 and 1975 in all three countries studied by them. Mark Schankerman and Ariel Pakes, "Estimates of the Value of Patent Rights in European Countries during the Post-1950 Period,' Economic Journal, vol. 96(December 1986), pp. 1052-76. See also the paper by Pakes and Simpson in this volume. 
turning up in the mid-1980s (see figure 2). Total R\&D expenditures in industry grew by about 8 percent a year between 1953 and 1968 and then declined by about 2 percent a year between 1968 and 1975 before turning up again. Some of the decline in the growth of domestic patenting (from 0.7 between 1953 and 1968 to -0.6 percent a year between 1968 and 1985) may be associated with this decline in the rate of growth of R\&D. The turnaround in patenting started in 1978, was interrupted by the recession of 1983 , and was much slower than the contemporaneous recovery in total R\&D spending.

Was this lack of growth in domestic patent applications due to a change in the industrial mix, away from the traditionally high-patenting areas (such as chemicals) and toward the faster-growing, lower-patenting industries such as computers? Table 3 presents some data on this point, using patents per R\&D dollar intensities in 1976 and reweighting them with the industrial distribution of company R\&D expenditures in 1957 and 1985. Computing a predicted average number of patents per R\&D dollar from these data yields results that go in the right direction, though the total effect is small: a -3 percent adjustment for the whole 1957-76 period. One gets similar results, not reported here in detail, using Scherer's data on 1974 patents by Lines of Business per R\&D dollar. ${ }^{6}$ In either case, the effects of industry mix are rather small, both because patenting intensities are not very different across industries and because the industrial composition of $\mathrm{R} \& \mathrm{D}$ did not change dramatically during this period.

That the observed declines in U.S. patenting are not just the result of compositional effects can also be seen from the available detail on patenting by industries and major companies. Table 4 gives industrial detail, in the form of annual growth rates between three-year averages, on patenting by U.S. residents (by year of grant) and by U.S. corporations (by year applied). These data are based on the "Concordance" constructed by the Office of Technology Assessment and Forecast, which takes data on the number of patents by patent class and assigns the classes, not uniquely, to potential industries of manufacture or use. The assignment rules can be and have been criticized (by Scherer and others), ${ }^{7}$ but the resulting detail should still be instructive. ${ }^{8}$ What table 4 shows is

6. F. M. Scherer, "Using Linked Patent and R\&D Data to Measure Interindustry Technology Flows," in Griliches, ed., $R \& D$, Patents, and Productivity, pp. 417-61.

7. Office of Technology Assessment and Forecast, "Review and Assessment of the 
Table 3. Industrial Distribution of Company-Financed R\&D and Patent Intensity per R\&D Dollar

\begin{tabular}{|c|c|c|c|c|}
\hline \multirow[b]{2}{*}{ Industry } & \multirow{2}{*}{$\begin{array}{c}\text { Number of } \\
\text { patents per } \\
\text { million dollars of } \\
\text { company-financed } \\
R \& D, 1976\end{array}$} & \multicolumn{3}{|c|}{$\begin{array}{l}\text { Percent of total company- } \\
\text { financed } R \& D \text { in specific } \\
\text { industry }\end{array}$} \\
\hline & & 1957 & 1976 & 1985 \\
\hline Food & 1.25 & 2.2 & 2.1 & 2.1 \\
\hline Textiles and apparel & 2.09 & 0.4 & 0.4 & 0.3 \\
\hline Lumber and paper & 1.89 & 1.5 & 2.3 & 2.0 \\
\hline Chemicals, excluding drugs & 1.53 & 15.3 & 9.8 & 9.6 \\
\hline Drugs & 1.31 & 6.1 & 6.4 & 7.0 \\
\hline Petroleum refining & 1.98 & 5.9 & 4.4 & 4.2 \\
\hline Rubber & 1.23 & 2.1 & 2.0 & 1.7 \\
\hline Stone, clay, glass & 2.68 & 2.1 & 1.4 & 1.0 \\
\hline Primary metals & 2.14 & 3.1 & 2.9 & 1.5 \\
\hline Fabricated metals & 2.26 & 3.0 & 1.8 & 1.2 \\
\hline Machinery, including computers & 1.16 & 12.1 & 17.4 & 18.5 \\
\hline Electric equipment & 2.22 & 11.5 & 9.6 & 9.5 \\
\hline Communication equipment & 2.16 & 7.1 & 8.5 & 10.8 \\
\hline Motor vehicles & 0.41 & 15.7 & 14.8 & 12.4 \\
\hline Aircraft & 0.78 & 9.1 & 8.2 & 8.3 \\
\hline Instruments & 1.10 & 4.3 & 6.7 & 9.4 \\
\hline Other & 1.50 & 1.1 & 1.3 & 0.7 \\
\hline \multicolumn{5}{|l|}{ Addendum } \\
\hline \multicolumn{5}{|l|}{$\begin{array}{l}\text { Estimated average number of } \\
\text { patents per million } R \& D\end{array}$} \\
\hline dollars using 1976 intensities & $\ldots$ & 1.43 & 1.38 & 1.39 \\
\hline
\end{tabular}

Sources: For number of patents, John Bound and others, "Who Does R\&D and Who Patents?' in Zvi Griliches, ed., $R \& D$, Patents, and Productivity (University of Chicago, 1984), table 2.3. For R\&D in 1957, National Science Foundation, Basic Research, Applied Research, and Development in Industry, 1962, NSF 65-18 (Washington, April 1965), p. 105 (some small industries estimates based on later year data); and for R\&D in 1976 and 1985, National Science Foundation, National Patterns of Science and Technology Resources, 1987, NSF 88-305 (Washington, January 1988), p. 59.

OTAF Concordance between the U.S. Patent Classification and the Standard Industrial Classification Systems: Final Report" (U.S. Department of Commerce, Patent and Trademark Office, January, 1985); a $\rightarrow$ F. M. Scherer, "The Office of Technology Assessment and Forecast Industry Concordance as a Means of Identifying Industry Technology Origins,' World Patent Information, vol. 4, no. 1 (1982), pp. 12-17.

8. The forty-two distinct manufacturing fields in the OTAF data base have been consolidated here to twenty-six to make them comparable to the applied R\&D data in table 5. For a discussion of the advantages and difficulties of using the R\&D data by product field, see Zvi Griliches and Frank Lichtenberg, "R\&D Productivity Growth at the Industry Level: Is There Still a Relationship?' in Griliches, ed., $R \& D$, Patents, and Productivity, pp. 465-96. In principle, the OTAF data are available back to 1967 and earlier but the recently revised concordance-based data have not been tabulated before 1970 by single years (by year of application). 
Table 4. Annual Growth Rates of U.S. Potents Granted by Potential Industry of Manufacture or Use, Three-Year Averages, 1968-80

Percent unless otherwise specified

\begin{tabular}{|c|c|c|c|c|c|c|c|c|}
\hline \multirow[b]{3}{*}{ Industry } & \multicolumn{4}{|c|}{ Patents granted to U.S. residents } & \multicolumn{4}{|c|}{$\begin{array}{c}\text { Patents assigned to U.S. } \\
\text { corporations }\end{array}$} \\
\hline & \multicolumn{3}{|c|}{ Date of issue } & \multirow{2}{*}{$\begin{array}{c}\text { Average } \\
\text { annual } \\
\text { number, } \\
1970-72\end{array}$} & \multicolumn{3}{|c|}{ Date applied for } & \multirow{2}{*}{$\begin{array}{c}\text { Average } \\
\text { annual } \\
\text { number, } \\
1970-72\end{array}$} \\
\hline & $1968-71$ & $1971-74$ & $1974-77$ & & $1971-74$ & $1974-77$ & $1977-80$ & \\
\hline Food & 9.6 & -2.1 & -6.8 & 483 & -2.1 & -5.7 & 0.8 & 312 \\
\hline Textiles & 8.2 & -7.0 & -1.7 & 365 & -4.3 & 0.1 & -3.0 & 233 \\
\hline Industrial chemicals & -1.1 & 0.1 & -2.8 & 3,922 & 0.5 & -3.5 & -5.1 & 3,064 \\
\hline Plastics & -5.6 & -5.8 & 0.6 & 731 & 0.4 & -1.7 & 0.6 & 528 \\
\hline Drugs & 8.9 & 8.0 & 12.3 & 395 & 13.6 & 6.3 & 0.2 & 350 \\
\hline Agricultural chemicals & 0.6 & 9.7 & 15.0 & 305 & 18.6 & 9.3 & -2.6 & 257 \\
\hline Petroleum refining & 0.3 & 0.0 & -4.1 & 716 & -2.2 & 4.1 & -2.4 & 584 \\
\hline Rubber & -1.1 & -0.5 & -0.9 & 1,931 & 0.5 & -1.6 & -0.7 & 1,358 \\
\hline Stone, glass, clay & 4.3 & -1.5 & -3.7 & 956 & -0.8 & -1.1 & 1.1 & 622 \\
\hline Ferrous metals & 1.6 & 3.7 & -9.2 & 227 & 1.4 & -8.2 & -1.8 & 163 \\
\hline Nonferrous metals & 4.5 & 0.8 & -2.8 & 243 & -3.0 & -1.5 & -4.5 & 183 \\
\hline Fabricated metals & -1.9 & 0.8 & -5.7 & 4,498 & -3.0 & -1.9 & -3.6 & 2,601 \\
\hline Engines & -1.4 & 9.4 & -1.0 & 315 & 6.1 & -7.6 & -0.4 & 233 \\
\hline Farm machinery & 2.9 & -0.5 & -6.8 & 838 & -0.9 & -1.6 & -3.6 & 383 \\
\hline $\begin{array}{l}\text { Construction } \\
\text { machinery }\end{array}$ & -1.4 & 0.0 & -7.4 & 1,651 & -2.8 & -3.6 & -1.2 & 1,008 \\
\hline $\begin{array}{l}\text { Metal working } \\
\text { machinery }\end{array}$ & 1.9 & -2.0 & -9.8 & 1,644 & -6.0 & -4.1 & -5.2 & 967 \\
\hline Office and computing & 7.6 & -4.6 & -2.9 & 1,254 & -1.2 & 1.0 & 3.4 & 844 \\
\hline $\begin{array}{l}\text { Electrical transmission } \\
\text { equipment }\end{array}$ & 2.7 & -6.8 & -6.3 & 1,200 & -6.8 & -4.5 & -2.6 & 867 \\
\hline $\begin{array}{l}\text { Electrical industry } \\
\text { apparatus }\end{array}$ & 1.0 & -9.7 & -6.3 & 1,433 & -3.7 & -5.9 & -0.2 & 850 \\
\hline $\begin{array}{l}\text { Other electrical } \\
\text { equipment }\end{array}$ & 0.0 & 0.0 & 6.1 & 1,208 & -1.9 & -0.5 & -3.7 & 789 \\
\hline $\begin{array}{l}\text { Communication } \\
\text { equipment }\end{array}$ & 5.5 & -3.2 & -5.0 & 5,992 & -1.3 & -1.6 & 0.7 & 3,618 \\
\hline $\begin{array}{l}\text { Motor vehicles and } \\
\text { equipment }\end{array}$ & -1.1 & 6.2 & -7.3 & 883 & -1.3 & -3.9 & -5.0 & 568 \\
\hline Aircraft and parts & -3.7 & 0.3 & -3.9 & 447 & -0.9 & -1.1 & -4.7 & 287 \\
\hline Guided missiles & -8.5 & -5.3 & -9.9 & 55 & -10.4 & 1.5 & -3.6 & 21 \\
\hline Ordnance & 0.4 & 9.5 & -7.3 & 283 & -9.2 & -1.8 & 3.8 & 111 \\
\hline Instruments & 8.7 & -1.5 & -5.4 & 6,199 & -1.1 & -2.0 & 0.5 & 3,668 \\
\hline Total U.S. & 1.6 & -1.2 & -4.9 & 56,528 & -1.8 & -2.1 & -1.6 & 32,103 \\
\hline
\end{tabular}

Sources: U.S. Patent and Trademark Office, Office of Documentation, "Patenting Trends in the United States, 1963-1987' microfiche, 1988; and earlier OTAF tabulations.

a. The growth rates are based on three year averages; that is, the entry for 1968-71 is

$$
\left(\frac{P(70)+P(71)+P(72)}{P(67)+P(68)+P(69)}-1\right) \frac{100}{3}
$$

where the notation 1968-71 signifies the midpoints of the two periods. 
that the decline in U.S. patenting in the 1970s was pervasive: almost all the industries, except drugs and agricultural chemicals, had significant declines or no growth in patenting during the early and middle 1970s. By the late 1970s the only visible recovery was in office and computing machinery and ordnance. Therefore the story would not change much by a reweighting of industries. This can also be seen in table 5, which lists the expenditures in U.S. industry on applied R\&D by product field for selected years and also the implied number of patents per AR\&D dollar in 1971. The latter numbers are rather wild, indicating problems with the Concordance, but the table as a whole clearly illustrates some of the conflicting trends in the data: both the strong growth in AR\&D in such low-patenting industries as office and computer machinery and the simultaneous declines in AR\&D in even less patent-intensive industries such as aircraft and guided missiles. ${ }^{9}$

Because of the difficulties of allocating specific patents to particular industries, it is perhaps easier to look at the actual numbers of patents received, by date applied for, for selected companies (figure 5). All the depicted U.S. companies show some decline in patents applied for and received during the early 1970 s as well as some recovery in the 1980 s. A common business-cycle effect is also apparent in 1973-75 and 1983 for most of the companies, including many of the foreign ones.

\section{Patenting and Research and Development}

The productivity slowdown of the 1970s was not the result of the slowdown in inventive activity, as measured by patent applications, U.S. or worldwide; more likely, a deterioration in economic conditions and expectations caused a decline in incentives for innovation. It is difficult, however, to observe the timing and to disentangle causation in such data. Data for the late 1960s already show some softness in the

9. Because of the ambiguity about which patent classes should be assigned to which industries, many of them are assigned to several industries simultaneously, in a fractional manner. Thus, for example, the numbers for patents in the drugs and agricultural chemicals industries are not really independent, since almost 90 percent of the patents assigned to both industries overlap. Similarly, the extremely high number of patents per AR\&D dollar in metal working machinery is probably the result of attributing to that industry many patents from fabricated metals and other kinds of machinery. 
Table 5. Applied R\&D Expenditures by Product Field, Selected Years, 1967-81

Millions of 1972 dollars unless otherwise specified

\begin{tabular}{|c|c|c|c|c|c|}
\hline Industry & 1967 & 1971 & 1975 & 1981 & $\begin{array}{c}\text { Patents } \\
\text { per } \\
\text { million } \\
R \& D^{a}\end{array}$ \\
\hline Food & 174 & 217 & 212 & 245 & 0.70 \\
\hline Textiles & 72 & 63 & 57 & n.a. & 0.27 \\
\hline Industrial chemicals & 719 & 707 & 672 & 856 & 4.33 \\
\hline Plastics & 617 & 535 & 458 & 527 & 1.01 \\
\hline Drugs & 451 & 560 & 609 & 914 & 0.63 \\
\hline Agricultural chemicals & 120 & 136 & 137 & 242 & 1.89 \\
\hline Petroleum refinery & 230 & 278 & 318 & 485 & 2.10 \\
\hline Rubber & 172 & 279 & 252 & n.a. & 4.86 \\
\hline Stone, glass, clay & 158 & 134 & 117 & 119 & 4.64 \\
\hline Ferrous metals & 152 & 119 & 112 & 133 & 1.37 \\
\hline Nonferrous metals & 118 & 121 & 114 & 206 & 1.51 \\
\hline Fabricated metals & 265 & 733 & 712 & 804 & 2.75 \\
\hline Engines & 250 & 257 & 361 & 450 & 0.91 \\
\hline Farm machinery & 133 & 94 & 107 & 138 & 4.07 \\
\hline Construction machinery & 155 & 205 & 222 & 283 & 4.92 \\
\hline Metal working machinery & 87 & 88 & 60 & 113 & 10.99 \\
\hline Office and computing & 799 & 945 & 1,215 & 1,602 & 0.89 \\
\hline $\begin{array}{l}\text { Electrical transportation } \\
\text { equipment }\end{array}$ & 139 & 163 & 110 & n.a. & 5.31 \\
\hline $\begin{array}{l}\text { Electrical industry } \\
\text { apparatus }\end{array}$ & 178 & 196 & 202 & n.a. & 4.34 \\
\hline $\begin{array}{l}\text { Other electrical } \\
\text { equipment }\end{array}$ & 309 & 313 & 240 & 325 & 2.72 \\
\hline $\begin{array}{l}\text { Communication } \\
\text { equipment }\end{array}$ & 3,353 & 3,062 & 3,042 & n.a. & 1.18 \\
\hline $\begin{array}{l}\text { Motor vehicle and } \\
\text { equipment }\end{array}$ & 983 & 1,284 & 1,339 & n.a. & 0.44 \\
\hline Aircraft and parts & 2,823 & 2,600 & 1,763 & 2,450 & 0.11 \\
\hline Guided missiles & 4,871 & 2,962 & 2,276 & 2,395 & 0.01 \\
\hline Ordnance & 284 & 201 & 145 & 225 & 0.55 \\
\hline Instruments & 697 & 682 & 780 & 739 & 5.38 \\
\hline Total U.S. AR\&D & 20,515 & 18,546 & 18,254 & 24,973 & 1.41 \\
\hline $\begin{array}{l}\text { Total U.S. corporate } \\
\text { patents }^{\text {b }}\end{array}$ & 32,512 & 32,103 & 29,878 & 26,848 & n.a. \\
\hline
\end{tabular}

Sources: National Science Foundation, Research and Development in Industry, annual reports; with data adjusted and interpolated as described in appendix of Zvi Griliches and Frank Lichtenberg, "R\&D and Productivity Growth at the Industry Level: Is There Still a Relationship?" in Griliches, ed., R\&D, Patents, and Productivity, pp. 465501 ; and with data deflated by R\&D price index from Griliches, "Comment on Mansfield," in $R \& D$, Patents, and Productivity, p. 149, and Bronwyn H. Hall and others, "The R\&D Master File Documentation," Technical Paper 72 (NBER, December 1988).

n.a. Not available.

a. Implied annual average number of U.S. corporate patents, 1970-72, per million of applied R\&D in 1971.

b. Three-year centered average, by date applied. 
growth of demand, as seen in the various total factor productivity growth numbers, ${ }^{10}$ arising in part from the end of the Vietnam War and the associated defense boom. Then the brief but sharp recession of 1971-72 was followed by the large and worldwide OPEC-induced oil price shocks of 1974 and 1979, and kept the world economy operating below capacity for a long time. ${ }^{11}$ Not surprisingly, therefore, inventive activity was also a depressed sector of the economy.

The notion that inventive activity is largely demand driven had its strongest proponent in Schmookler, who used patent data from the late nineteenth and early twentieth centuries to show that inventive activity (as measured by patents) was related to earlier movements in investment and output of the relevant industries. ${ }^{12}$ His work can be, and has been, criticized on several levels. In the longer run, supply forces in the form of new discoveries and the steady contribution of new scientific knowledge surely have an important role to play. ${ }^{13}$ Moreover, by current econometric standards the evidence presented by Schmookler for his conclusions does not seem all that strong (though it gains conviction by the cumulative force of the various bits and pieces examined, and by the impression of a knowledgeable, first-rate mind grappling with the problem and coming to a considered judgment). Subsequent empirical work on this topic has either supported his original conclusions or weakened them, but no one has overturned them. ${ }^{14}$ In general, at the level of annual

10. See, for example, William D. Nordhaus, "The Recent Productivity Slowdown," $B P E A, 3: 1972$, pp. 493-536; and Dale W. Jorgenson, Frank M. Gollop, and Barbara M. Fraumeni, Productivity and U.S. Economic Growth (Harvard University Press, 1987).

11. Zvi Griliches, "Productivity Puzzles and R\&D: Another Nonexplanation," Journal of Economic Perspectives, vol. 2 (Fall 1988), pp. 9-21.

12. Schmookler, Invention and Economic Growth.

13. Nathan Rosenberg, "Science, Invention and Economic Growth," Economic Journal, vol. 84 (March 1974), pp. 90-108.

14. F. M. Scherer, "Firm Size, Market Structure, Opportunity, and the Output of Patented Inventions,"' American Economic Review, vol. 55 (December 1965), pp. 10971123; F. M. Scherer, "Demand-Pull and Technological Invention: Schmookler Revisited," Journal of Industrial Economics, vol. 30 (March 1982), pp. 225-37; Paul Stoneman, "Patenting Activity: A Re-evaluation of the Influence of Demand Pressures,' Journal of Industrial Economics, vol. 27 (March 1979), pp. 385-401; Geoffrey Wyatt, The Economics of Inventions: A Study of the Determinants of Inventive Activity (St. Martin's Press, 1986);

$\rightarrow$ Derek Bosworth and Tony Westaway, "The Influence of Demand and Supply Side Pressures on the Quantity and Quality of Inventive Activity," Applied Economics, vol. 16 (January 1984), pp. 131-46; Christos Papachristodoulou, "Inventions, Innovations, and Economic Growth in Sweden: An Appraisal of the Schumpeterian Theory," Ph.D. 
Figure 5. U.S. Patents Granted to Selected Firms, by Date Applied For, 1968-84

Number A. ELECTRONIC FIRMS

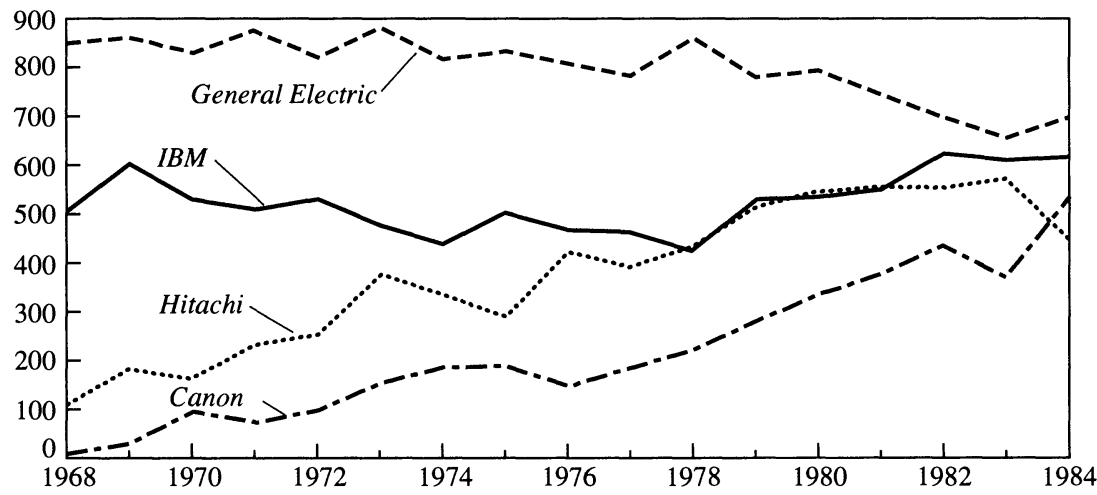

Number

B. CHEMICAL FIRMS

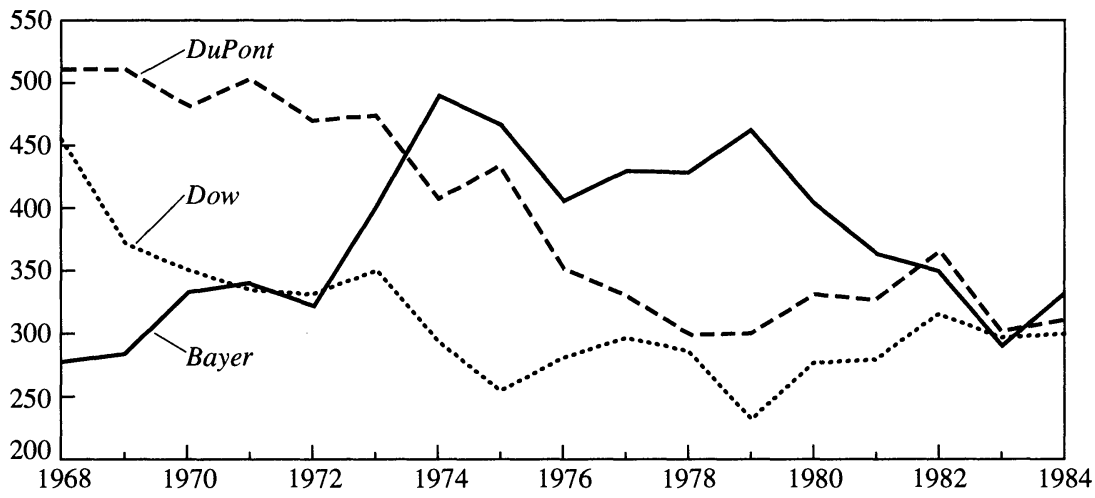

Number

C. AUTOMOBILE FIRMS

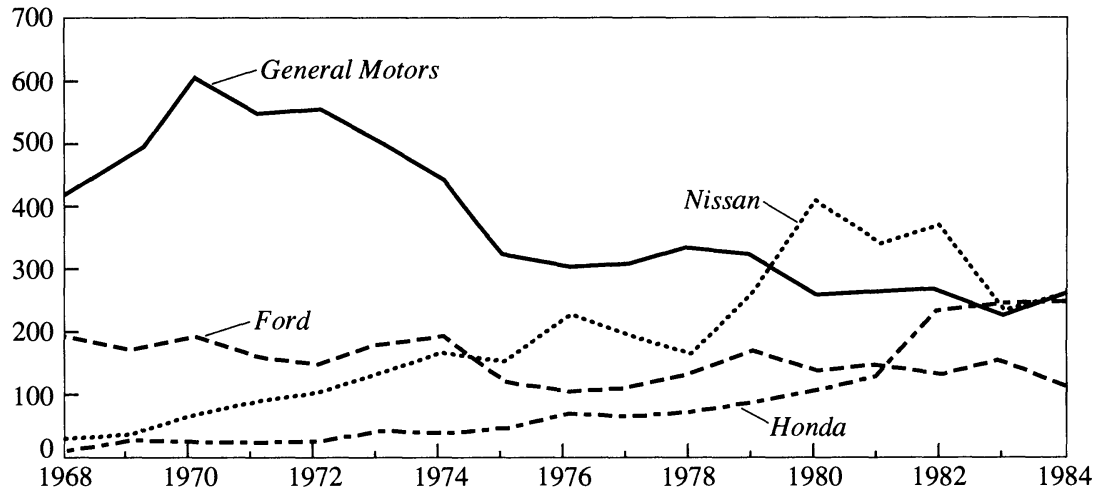

Source: U.S. Patent and Trademark Office, Office of Documentation, "Patenting by Organizations," March 1988 and earlier releases. 
fluctuations demand forces are likely to be more important and easier to detect than the much slower supply forces, whose effects take longer to accumulate. ${ }^{15}$

It should be noted that insofar as the focus is on the decline in patenting relative to the growth in $R \& D$ expenditures, demand forces, at least to a first approximation, have already been taken into account. They are reflected in the R\&D series, which themselves represent an investment in the future, and are the main channel through which demand forces can and do affect the level of patenting. The additional fall in the propensity to patent, in patents per R\&D dollar, could also arise from demand forces if, because of differential adjustment costs, they affect the patenting decision more rapidly than the decision to invest in R\&D. Other reasons for this decline may be shifts of $R \& D$ to areas where patenting is less profitable and perhaps more difficult, or an overestimation of the growth in real $R \& D$ due to an underestimation, by the conventional R\&D deflators, of the growth in the real cost of doing science, in finding new drugs and new compounds, and in designing new chips. Thus allowing the real cost of doing $R \& D$ to rise by about 3-4

dissertation, Uppsala University, 1986; and Alfred Kleinknecht and Bart Verspagen, "Is Innovation a Function of Demand? Schmookler Re-examined,' University of Limburg, the Netherlands, 1988. Several studies, following Stoneman, have regressed the log of patents on the log of $R \& D$ per patent, interpreting the second variable as a measure of the cost of invention, and the resulting negative coefficient as an indication of the workings of supply forces. But the sign of this coefficient could reflect nothing more than the spuriousness of such a relationship, induced by the large transitory or measurement error component in patent numbers. On the latter possibility see Zvi Griliches, Bronwyn H. Hall, and Ariel Pakes, "R\&D, Patents, and Market Value Revisited: Is There a Second (Technological Opportunity) Factor?’' Working Paper 2624 (Cambridge, Mass.: National Bureau of Economic Research, June 1988).

15. Taking the longer-run view and looking at periods with no $R \& D$ data, one can reproduce the main outlines of Schmookler's results. For example, for the whole 1880-87 period (eighty-eight years), one gets (in first differences of logarithms format):

$$
\begin{gathered}
\text { gda }=-0.006+0.110 \text { ggpdi }+0.299 \text { ggnp }(-1), \\
\quad(0.009) \quad(0.030) \quad(0.128) \\
\bar{R}^{2}=0.15 ; \text { standard error }=0.075 ; \text { Durbin-Watson }=1.87
\end{gathered}
$$

where the rate of growth in domestic patent applications ( $g d a)$ is related positively to the current rate of growth in gross private domestic investment (ggpdi) and the lagged rate of growth in real GNP (ggnp). Because the post-World War II period exhibits much less variance, the results are weaker then, but not all that different. For that period there are, however, actual direct input measures, such as R\&D expenditures and the number of scientists and engineers engaged in $R \& D$, which dominate the aggregate economy indexes like GNP or GPDI. 
percent more a year than is indicated by the conventional deflators would eliminate most or all of this decline. ${ }^{16}$ But it is difficult to distinguish this explanation from various other hypotheses about the exhaustion of the scientific frontiers. Why is the cost of real science rising faster than a reasonably weighted index of scientific salaries and a quality-adjusted price index of scientific instruments and equipment? Is competition from other scientists within the country and abroad driving up the resources necessary to produce a unit of visible advance in a field? Is it just a reflection of diminishing returns to $R \& D$ investments when they are applied to a fixed or a slower-growing underlying set of scientific opportunities, that is, a crowding out and a fishing out? ${ }^{17}$

Table 6 presents several different attempts to explain the aggregate number of total domestic patent applications in the United States during the last thirty years or so. Because reasonably consistent R\&D data at the national level do not exist before 1953, most of the analysis is based on the 1954-87 period. I look here at several issues. How much of the decline in domestic patenting in the 1970s can be attributed to the decline in real $R \& D$ expenditures during the same period? Do domestic patents depend largely on company-financed $R \& D$ expenditures or on total $R \& D$ in the economy, including university $R \& D$ ? Did changes in the demands of the defense establishment impinge positively or negatively on domestic inventive activity? Can part of the decline in the propensity to patent be explained by the rising real cost of R\&D? Because of the shortness of the period, the highly aggregated nature of all the variables, and the rather common trendlike movement in most of them, such questions cannot be answered definitively, but the findings summarized in this table are suggestive, nevertheless.

First, for the period as a whole (1953 through 1987) there was no significant decline in the number of patent applications in the United

16. See Daniel W. Smith, "Will Producing More Scientists and Engineers Produce a More Innovative America?' Boston University, Center for Technology and Policy, 1988. According to Cohen and Ivins, "For an institution viewed as a whole, with a constant complement of young scientists, typical weighted growth rates per scientist (in the "'sophistication factor") might be $2-5$ percent in constant-value terms per annum." Adrian V. Cohen and L. N. Ivins, The Sophistication Factor in Science Expenditure, Council for Scientific Policy, Science Policy Studies 1 (London: Her Majesty's Stationery Office, 1967), p. 28.

17. For further discussion, see Englander and others, "R\&D, Innovation, and the TFP Slowdown." 
Table 6. Determinants of Applications for U.S. Patents by U.S. Residents, 1953-87 ${ }^{\text {a }}$

\begin{tabular}{|c|c|c|c|c|c|c|}
\hline \multirow[b]{3}{*}{ Variable $^{\mathrm{b}}$} & \multicolumn{6}{|c|}{$\begin{array}{c}\text { Regression coefficients } \\
\text { 1954-87 }\end{array}$} \\
\hline & $1953-87$ & & & & & \\
\hline & (1) & (2) & (3) & (4) & (5) & (6) \\
\hline Time & $\begin{array}{c}-0.000 \\
(0.001)\end{array}$ & $\begin{array}{c}-0.017 \\
(0.005)\end{array}$ & $\begin{array}{c}-0.018 \\
(0.004)\end{array}$ & $\begin{array}{c}-0.013 \\
(0.003)\end{array}$ & $\begin{array}{r}-0.007 \\
(0.004)\end{array}$ & $\begin{array}{r}-0.007 \\
(0.001)\end{array}$ \\
\hline$D L N T D F$ & $\ldots$ & $\ldots$ & $\begin{array}{c}-0.279 \\
(0.097)\end{array}$ & $\begin{array}{r}-0.317 \\
(0.084)\end{array}$ & $\begin{array}{r}-0.314 \\
(0.074)\end{array}$ & $\begin{array}{c}-0.314 \\
(0.077)\end{array}$ \\
\hline$D L N T D F(-1)$ & $\ldots$ & $\ldots$ & $\begin{array}{r}-0.257 \\
(0.098)\end{array}$ & $\begin{array}{c}-0.203 \\
(0.081)\end{array}$ & $\begin{array}{c}-0.155 \\
(0.084)\end{array}$ & $\begin{array}{c}-0.155 \\
(0.076)\end{array}$ \\
\hline$L C R D(-1)$ & $\ldots$ & $\begin{array}{c}0.338 \\
(0.094)\end{array}$ & $\begin{array}{c}0.410 \\
(0.075)\end{array}$ & $\begin{array}{c}0.203 \\
(0.090)\end{array}$ & $\begin{array}{c}0.000 \\
(0.125)\end{array}$ & $\ldots$ \\
\hline $\operatorname{LRUNBR(-1)}$ & $\ldots$ & $\ldots$ & $\ldots$ & $\begin{array}{c}0.064 \\
(0.019)\end{array}$ & $\begin{array}{c}0.121 \\
(0.032)\end{array}$ & $\begin{array}{c}0.121 \\
(0.015)\end{array}$ \\
\hline$L R R D D F$ & . & . & $\cdot$ & . & $\begin{array}{r}-0.775 \\
(0.352)\end{array}$ & $\begin{array}{r}-0.776 \\
(0.233)\end{array}$ \\
\hline
\end{tabular}

\section{Summary statistics}

Standard deviation

\begin{tabular}{rclllll}
\multicolumn{1}{r}{ of estimated residuals } & 0.0507 & 0.0425 & 0.0326 & 0.0281 & 0.0264 & 0.0259 \\
$\bar{R}^{2}$ & -0.029 & 0.256 & 0.561 & 0.674 & 0.713 & 0.724 \\
Durbin-Watson & 0.72 & 1.21 & 1.74 & 2.00 & 2.04 & 2.02 \\
\hline
\end{tabular}

Sources: For R\&D data, National Science Foundation, National Patterns of Science and Technology Resources, 1986, NSF 86-309 (Washington, 1986), and National Science Board, Science and Engineering Indicators, 1987, NSB 87-1 (Washington, 1988). For GNP and related data: before 1929, Bureau of the Census, Long Term Economic Growth, 1860-1965: A Statistical Compendium, ES 4-1 (Department of Commerce, October 1966); for 1927-87, "Summary National Income and Product Series: Annually, 1929-86, and Quarterly, 1960-86,"' Survey of Current Business, vol. 67 (September 1987), pp. 56-63; and for 1988, Economic Report of the President, January 1989, app. B.

a. Dependent variable is log of domestic patent applications.

b. $D L N T D F=$ the rate of growth in the national defense component of real GNP $L C R D=\log$ of company-financed R\&D expenditures in industry, deflated

$L R U N B R=\log$ of total "real" basic research expenditures in universities, deflated $L R R D D F=\log$ of the ratio of the R\&D to the implicit GNP deflators.

c. Numbers in parentheses are standard errors.

States by U.S. residents. Since real R\&D grew at a positive rate over this period, at least if one uses the standard deflators, any attribution of a positive influence to them will imply the finding of a negative time trend in the patents' production function. Second, fluctuations in R\&D do affect the number of patents applied for, but less than proportionately. Among the various possible measures of $R \& D$, company expenditures on $R \& D$ work best as long as only one measure of $R \& D$ is to be included in the equation. These first two findings together imply a negative trend 
in the propensity to patent or in the efficiency of patent production of about -1 to -2 percent a year. The estimated coefficient of the company $R \& D$ variable is quite high and significant, between 0.2 and 0.4 , and is consistent with earlier findings based on microeconomic data. ${ }^{18}$ Third, changes in the size of the defense establishment, in the form of current and lagged changes in real gross national product devoted to national defense, have a significantly negative effect on the number of domestic patents applied for and perhaps also on actual levels of inventive activity. The estimated effect is large-a 10 percent increase in defense GNP causes a 5 percent decline in domestic patenting-and it is quite robust to the introduction or deletion of other variables. This finding is consistent with both the view that defense expenditures pull resources away from inventive activity and the view that they channel inventive activity into areas in which patenting is either more difficult or less important. ${ }^{19}$ Fourth, these data suggest that basic research in universities contributes positively to the overall level of domestic inventive activity as measured by the total number of domestic patent applications. Finally, there is some evidence that the rising real cost of $R \& D$, in the form of the ratio of the R\&D to GNP price deflators, has had a negative effect on patenting, either because it also reflects the rising cost of patenting relative to other economic activities, or because it adjusts in part for the underdeflation of the R\&D variables by the same set of deflators. These conclusions are all very tentative, since, as noted earlier, they are based on highly aggregated data, a short time period, and a highly multicollinear set of examined variables. The last point is made clear by the insignificance of the company $R \& D$ variable once the real $R \& D$ deflator variable is added to the equation and is reinforced by the high intercorrelation that exists between most of these variables. The simple correlation of the company $R \& D$ variable with time and real GNP is 0.99 and 0.98 respectively, and it is about 0.94 with university basic research or total R\&D in industry. It would be desirable, therefore, to confirm some of these conclusions by using better and more detailed data at a less aggregated level.

18. Bronwyn H. Hall, Zvi Griliches, and Jerry A. Hausman, "Patents and R\&D: Is There a Lag?' International Economic Review, vol. 27 (June 1986), pp. 265-83.

19. Attempts to extend these results by adding more demand-side variables, such as changes in real GNP, capacity utilization, and stock price indexes, were not successful. Almost all the systematic short-run variability in aggregate domestic patenting is picked up by fluctuations in the R\&D and national defense variables. All the other demand variables seem to work through those variables. 
Earlier work with microeconomic data on related topics is consistent with most of these conclusions. Using firm data on patents and R\&D, Pakes, Hall and others, and Griliches and others found that, so far as it is testable, causality runs from $R \& D$ to patents. ${ }^{20}$ This relationship is almost instantaneous, with some evidence of longer lags present but difficult to establish precisely. Nearly all the other economic variables they examined, such as the stock market rate of return, sales, and investment, work primarily through the $R \& D$ variables and do not make a significant independent contribution of their own to the various estimated patent equations. The estimated coefficients of the R\&D variables in the time dimension of such equations (in first differences or "within" a firm) were between 0.2 and 0.4 . The small size of such coefficients and the absence of a significant finding of direct effects of demand-side macro-related variables do not make the interpretation of the patenting trends at the aggregate level any easier.

An attempt has also been made to use the industry-level data already presented in tables 4 and 5. Unfortunately the data on patents received by year applied for are not available before 1970 and are incomplete after 1983. Moreover, the applied R\&D data are seriously incomplete after 1979, with the National Science Foundation reporting significantly less industrial detail for this variable. Running patent-R\&D equations on these data in the first differences of logarithms format, including separate year and industry dummy variables, and limiting the analysis to the complete data years 1970-79 yields no evidence of a significant lag structure and an estimate of $0.27(0.08)$ for the elasticity of corporate patents received with respect to AR\&D. Adding current and three lagged values in output or capital growth, or both, and lagged values of growth in AR\&D improves matters very little. In the "best" equation changes in corporate patents received (by year applied for) depend only on current changes in AR\&D, with a coefficient of $0.22(0.07)$, and two periods lagged growth rate of output, with a coefficient of $0.23(0.11)$. Since during this period, 1971-79, the average growth rates of output and real AR\&D as measured are both positive, the implied estimate of the trend rate on the propensity to patent is still negative, and in fact, more negative than the observed trend in the raw numbers. Thus a

20. Ariel Pakes, “On Patents, R\&D, and the Stock Market Rates of Return," Journal of Political Economy, vol. 93 (April 1985), pp. 390-409; Hall and others, "Patents and R\&D' ; and Griliches and others, "R\&D, Patents, and Market Value Revisited.", 
positive role for such variables in the patenting relationship is inconsistent with the hope that they would contribute to an explanation of the observed negative trends in these data. The estimated trend remains negative for all the years except 1975, and for all the industries except drugs and agricultural chemicals. Adding post-1979 data for some of the industries, where they are available, does not change the results appreciably.

Returning to table 6 and the associated macroeconomic data, one can summarize its conclusions as follows. During the 1970-79 peak-to-trough period in domestic patenting, there was an average decline (in patents applied for by U.S. residents) of about 2 percent a year, of which about a third, or 0.7 percent, could be attributed to the accelerating growth in the U.S. defense establishment. At the same time, however, companyfinanced $R \& D$ expenditure and basic research expenditures in universities grew at about 2 percent and 1 percent a year respectively. Using the estimated coefficients from column 4 in table 6 would imply that this growth should have resulted in about 0.5 percent a year growth in patent applications, canceling out most of the negative effect of the growth in defense and leaving almost all the observed decline in patenting unexplained. A similar computation for the whole 1954-87 period would find no actual decline in patenting to explain and also no substantive change in the rate of growth of defense. But unless the R\&D deflators are all wrong, the data do indicate growth in both private company $R \& D$ expenditures in industry and basic R\&D expenditures in universities, 5 and 8 percent a year respectively, which should have resulted in some increase in the observed rate of patenting. Thus there still remains a significant unexplained decline in U.S. patenting relative to the ongoing investment in $R \& D$.

\section{Patenting and Diminishing Returns}

Aggregate numbers of patents (applied for and granted) have fluctuated greatly in the past. They have also grown slowly in this century, much less so than investments in R\&D, which has led scholarly observers to wonder repeatedly about the implied slackening in the growth rate of technical progress. In 1935 Merton wrote, "In the U.S., however, the number of patents has scarcely kept pace with the growth of population since 1885-a fact which may lead us to suspect the possibility of a 
slackening in the rate of technologic advance generally." At the same time, Gilfillan was blaming the decline in patenting on the decline in the native ability of the American people, due to immigration and dysgenics, since "the stupid have been breeding at a much higher rate." ${ }^{21}$ In 1952 Stafford wondered if the rate of invention was declining, since he observed a declining trend in patenting, from 1916 through 1947, in twothirds of all the patent classes and worried about diminishing returns on the one hand and the increasing complexity of invention on the other. ${ }^{22}$ The same point was taken up by Scherer in 1959: "The sharp decline in patenting during the depressed 1930's can be attributed to unfavorable economic conditions, while the slump during World War II is explained by the historical tendency for patenting to decline during wartime. But no such ready explanation is available for the continued record of sluggishness during the booming postwar period." ${ }^{23} \mathrm{He}$ then attributed some of this decline, as did Schmookler later on, to a change in the judicial climate and especially to the increase in compulsory licensing decrees. ${ }^{24}$ But that does not seem to explain all the decline, or its persistence into the 1970s. And this type of worry continues to this day, as can be seen in Baily and Chakrabarti, Scherer, and this paper. ${ }^{25}$ One can always worry that the world is coming to an end. Someday it undoubtedly will, but it does not look as if the end is already upon us, at least not yet.

What are the facts so far as they can be discerned? There has been no absolute decline in the rate of patenting in the United States. Total patent grants and applications are now running about 30 percent above what

21. Robert K. Merton, "Fluctuations in the Rate of Industrial Invention," Quarterly Journal of Economics, vol. 49 (May 1935), p. 454; and S. C. Gilfillan, "The Decline of the Patenting Rate, and Recommendations,' Journal of the Patent Office Society, vol. 17 (March 1935), pp. 218-19.

22. Alfred B. Stafford, "Is the Rate of Invention Declining?" American Journal of Sociology, vol. 57 (May 1952), pp. 539-45. Stafford's paper is a marvelous example of how easy it is to make wrong predictions about the future. See also the sharp and confused exchanges between Gilfillan, Schmookler, and Kunik in Technology and Culture in 1959. S. C. Gilfillan, "An Attempt to Measure the Rise of American Inventing and the Decline of Patenting," Technology and Culture, vol. 1 (1959), pp. 201-14; Jacob Schmookler, "An Economist Takes Issue," pp. 214-20; and I. Jordan Kunik, "A Patent Attorney Takes Issue," pp. 221-27.

23. Scherer, Patents and the Corporations, p. 130.

24. Schmookler, Invention and Economic Growth.

25. Baily and Chakrabarti, Innovation and the Productivity Crisis; and F. M. Scherer, "The World Productivity Growth Slump," in Rolf Wolff, ed., Organizing Industrial Development (Berlin: Walter de Gruyter, 1986), pp. 15-27. 
they were in the early 1960s, and U.S. domestic patent applications have also recovered to the levels attained in the 1960s. This raises the question whether we need a growing rate of invention (if patent numbers do indeed measure it) to sustain a steady positive rate of growth in total factor productivity. Does the faster growth in real $R \& D$ expenditures indicate diminishing returns to $R \& D$ or an improvement in the quality of patented inventions? And could the 11 percent decline in the average number of domestic patent applications between 1968-71 and 1977-83 have been responsible for the productivity slowdown in the 1970s or have significant implications for productivity growth in the future?

Insofar as an invention either reduces the cost of production or develops entirely new products, it has an aspect of increasing returns to it. The same invention could produce the same proportional effect in different size markets or economies. The public-good nature of most inventions and the multiplicative aspect of their effect do not require, therefore, that their number grow just to sustain a positive rate of productivity growth. However, economies do not grow just by replication and expansion; they also get more complex, proliferate different products and activities, and develop in different geographic and economic environments. To that extent, the reach of any particular invention does not expand at the same rate as the growth of the overall economy, but only at the rate of growth of its own market. I would therefore expect that the required number of inventions for a steady positive rate of growth in productivity must also grow, but at a rate that need not be as fast as that of the economy as a whole.

What I have just discussed is the fundamentally unobservable quantum of "invention" or "an advance in knowledge." Clearly, its relationship to observed patent numbers is unlikely to have stayed constant over time. But the important question is what an observed decline in patent numbers implies about the underlying stream of inventions and their ultimate effect on productivity. If the decline occurs because of a rise in the real cost of patenting, or even of a decrease in the expected value of the marginal patent, it may still have little effect on the aggregate contribution of inventive activity, given the great dispersion in the private and social values of the inventions associated with these patents.

The dispersion in patent values has been documented and commented on in the past by Sanders, Scherer, and Nordhaus, among others, and more recently by Pakes, Schankerman and Pakes, and Griliches and 
others. ${ }^{26}$ Their evidence shows that most patents are worth very little and that the bulk of the private and social total product of the inventive system is based on a relatively small number of valuable patents. If the value of a patent were known to the inventor in advance, then a rise in the cost of patenting or a decline in the return from inventing would deter only the marginal, low-value inventive activity, leaving the total aggregate return effectively unchanged. Inventors are unlikely, however, to know the value of their inventions in advance. At the other extreme, one could assume that all the estimated dispersion in patent values is within; that all of it represents the uncertainty that confronts each individual inventor. Then a decline in patent number would imply a parallel decline in total inventive activity and results. ${ }^{27}$ Undoubtedly inventors do face great uncertainty about the ultimate value of their inventions, as is emphasized and documented by Pakes, but it is probably not as extensive as implied by the estimated cross-sectional dispersion in patent values. The truth, I believe, is somewhere in the middle, where some definite knowledge exists about the potential importance of the particular invention. If so, and this is also what can be read into the numbers reported in Schankerman and Pakes, a decline in patenting would be associated with an increase in the average value of a patent, and with a much smaller effect, if any, on the aggregate valuation of this activity.

Even if there were a real decline in inventive output associated with the observed decline in patent numbers, for several reasons its effects would not be readily discernible in the conventional productivity numbers. First, not all productivity growth is due to invention, and only a

26. Barkev Sanders, "Patterns of Commercial Exploitation of Patented Inventions by Large and Small Corporations,'" Patent, Trademark, and Copyright Journal of Research and Education, vol. 8 (Spring 1964), pp. 51-92; Scherer, "Firm Size, Market Structure', William D. Nordhaus, "An Economic Theory of Technological Change," American Economic Review, vol. 59 (May 1969, Papers and Proceedings, 1968), pp. 18-28; Ariel Pakes, "Patents as Options: Some Estimates of the Value of Holding European Patent Stocks," Econometrica, vol. 54 (July 1986), pp. 755-84; Schankerman and Pakes, "Estimates of the Value of Patent Rights"; and Zvi Griliches, Ariel Pakes, and Bronwyn H. Hall, "The Value of Patents as Indicators of Inventive Activity,"' in Partha Dasgupta and Paul Stoneman, eds., Economic Policy and Technological Performance (Cambridge University Press, 1987), pp. 97-124.

27. This is one way to read the evidence presented by Mansfield that major U.S. corporations have not reduced the fraction of their inventions that they patent. Edwin Mansfield, “Patents and Innovation: An Empirical Study,' Management Science, vol. 32 (February 1986), pp. 173-81. 
fraction of the latter comes from patented inventions. If one takes 1.5 to 2.0 percent as the approximate annual growth rate in total factor productivity, at least half is probably due to the growth in the quality of the labor force, economies of scale, and various reallocations of capital between assets and industries. Moreover, it is unlikely that patented inventions could account for more than half of all the relevant advances in knowledge. That leaves at most a quarter of total productivity growth, and an unknown fraction of its fluctuations, to be attributed to patented invention. ${ }^{28}$

Second, since the effects of an invention on productivity appear with a long and variable lag, it is doubtful that the available data and current econometric techniques could identify them clearly. Further, the aggregation over many inventions and many lag structures is likely to smooth out the effects beyond recognition.

Third, the great variability in the magnitude and importance of the different inventions adds another source of variance. Given the large skewness in the value distributions, one cannot take much comfort from the relatively large sample or, rather, population numbers. If, for example, one were to approximate the value distribution by a spike, assuming that 999 patents are worth nothing while 1 out of the 1,000 has a present value of $\$ 500$ million and an annual real flow equivalent (at a 3 percent real interest rate) of $\$ 15$ million a year, that would imply a standard deviation of $\$ 121$ million for the expected total value of flows from newly patented inventions of $\$ 975$ million. ${ }^{29}$ If about one-third of the 10 percent decline in domestic patent applications between the late 1960 s and late 1970s were to translate itself into a decline in real innovative

28. Taking $\$ 0.5$ million as the midpoint between the low and high estimates of the average present value of a patent right from Griliches and others, and 65,000 as the average number of patents a year in the 1980 s and a 3 percent real interest rate, yields about $\$ 1$ billion as an estimate of the annual increment in private returns. Taking 1.5 percent as the growth rate of total factor productivity would yield an annual increment in private nonresidential GNP in 1982 of $\$ 47$ billion attributable to the growth in productivity, of which a quarter, about $\$ 12$ billion, could be the result of patented inventions. This amount would require that the social return from these inventions be at least ten times larger than the private return from the ownership of patent rights. That is clearly possible but perhaps not very plausible.

29. With 15 as the expected value of a success, 0.001 as its probability, and $n=65,000$,

and

$$
E(x)=15 \cdot 0.001 \cdot 65,000=975
$$

$$
\sigma_{x}=15 \cdot \sqrt{65}=121 .
$$


output, one would be looking to detect a $\$ 32$ million decline in the expected annual flow. With a standard deviation of $\$ 121$ million a year, more than seven years would be needed, not counting any lags, to detect the decline with any statistical confidence even if there were no other sources of variation in productivity. And in the meantime it might have turned itself around. It is this great variability in relative importance of individual patents, together with a variable lag structure, that makes detecting such phenomena so difficult, a point that Nordhaus made in 1969. ${ }^{30}$ Insofar as one does observe correlations between patent numbers and contemporaneous productivity numbers, causality is most likely running the other way, from productivity as a measure of the economic environment to patents as a measure of inventive effort rather than from the effect of inventive output on subsequent productivity.

The question of diminishing returns to $R \& D$ and the implicit forecast of a declining productivity growth rate also remains unresolved. If the relationship of patent numbers to inventive output has been changing, then these numbers cannot be used to answer that question. The other evidence on this topic is also equivocal. A priori one would expect to hit diminishing returns in any narrowly defined field, at least until the field or the product area is redefined anew by another major breakthrough. Kuznets used detailed patent data to make this point in 1930. It also follows from the various theoretical models of the R\&D process, such as Evenson and Kislev's. ${ }^{31}$ Inventive effort, however, moves from one fishing ground to another, and new fishing grounds open up as the result of basic R\&D and other sources of discovery. Thus, in the longer run, there is less evidence of exhaustion of opportunities, and studies that have tried to look for declines in the rates of return to R\&D have found very little evidence of them. ${ }^{32}$ The same conflict appears in the various estimates of the patent production function. Time-series estimates, which presumably measure returns to movements primarily along al-

30. Nordhaus, "An Economic Theory of Technological Change."

31. Simon S. Kuznets, Secular Movements in Production and Prices: Their Nature and Their Bearing upon Cyclical Fluctuations (Houghton Mifflin, 1930), pp. 54-58; and Robert E. Evenson and Yoav Kislev, Agricultural Research and Productivity (Yale University Press, 1975), chap. 8.

32. See, for example, Zvi Griliches, "Productivity, R\&D, and Basic Research at the Firm Level in the 1970s," American Economic Review, vol. 76 (March 1986), pp. 141-54; and Leo Sveikauskas, "Productivity Growth and the Depletion of Technological Opportunities," Bureau of Labor Statistics, 1988. 
Figure 6. Multifactor Productivity in the Private Business Economy, and Patent and R\&D Capital Stocks, 1947-87

Log scale

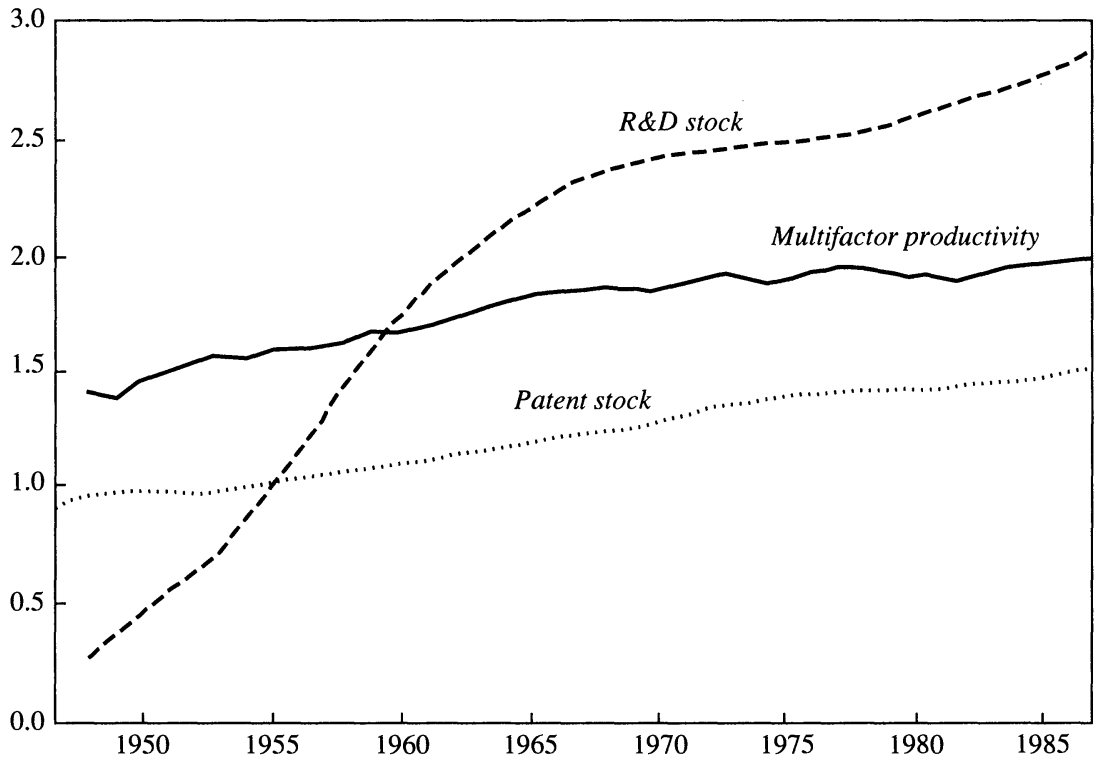

Sources: R\&D and patent stocks computed from aggregate data from tables 2, 4, and 5, using a 15 percent declining balance depreciation formula and estimated initial conditions. Multifactor productivity estimates from U.S. Bureau of Labor Statistics, "Multifactor Productivity Measures, 1987," News, September 20, 1988.

ready established trajectories, all tend to come out with relatively low elasticities of patents received with respect to $R \& D$ invested, on the order of 0.2 to $0.45 .{ }^{33}$ In contrast, cross-sectional studies, which presumably better represent the optimal migration of $R \& D$ resources across fields and the finding of new niches, yield elasticity estimates much closer to unity. ${ }^{34}$

Most R\&D-based models of productivity and productivity growth already contain the assumption of diminishing returns. In such models,

$\rightarrow$ Ariel Pakes and Zvi Griliches, "Patents and R\&D at the Firm Level: A First Report," Economic Letters, vol. 5, no. 4 (1980), pp. 377-81; Jerry A. Hausman, Bronwyn H. Hall, and Zvi Griliches, "Econometric Models for Count Data and with an Application to the Patents-R\&D Relationship," Econometrica, vol. 52 (July 1984), pp. 909-38; and Hall and others, "Patents and R\&D."

34. See John Bound and others, "Who Does R\&D and Who Patents?" in Griliches, ed., $R \& D$, Patents, and Productivity, pp. 89-123; $\rightarrow$ F. M. Scherer, "The Propensity to Patent,'” International Journal of Industrial Organization, vol. 1 (1983), pp. 107-28. 
with the stock of knowledge capital proxied by a stock of accumulated past R\&D expenditures, the estimated elasticities tend to be rather small, about 0.06 to $0.20 .^{35}$ These, by the way, are not much different from the time-series-based patent-R\&D coefficients estimates discussed earlier. If productivity is a measure of knowledge accretion and patents are a proxy index for it, no paradox may exist here after all. That is what is also implied by figure 6 , which plots (on a common logarithmic scale) the index (level) of multifactor productivity in the private business sector of the U.S. economy (as computed by the Bureau of Labor Statistics) together with a measure of the total stock of patent applications in the United States and the parallel concept of the stock of total R\&D expenditures (both based on a 15 percent depreciation rate). Note the remarkably similar behavior of productivity and the total patent stock and the faster growth rate, at least during the earlier part of the period, of the total R\&D stock. If only domestic patent applications had been counted, the patent stock variable would have turned down significantly by the mid-1980s. That is evidence for my view that the relevant indicator for measures of technical change is total patents, not just domestic patents.

In the past I looked at such charts and thought that something was wrong with the productivity numbers. But if we are to believe the patent numbers, perhaps they are not so wrong after all. For reasons already discussed, I think that over longer periods of time patent numbers are an imperfect index of inventive output, whose relationship to the underlying shift in frontiers has been declining over time. More will have to be learned, however, before one can feel certain about such inferences. Thus the patent numbers leave us where we began, with a suggestive, but possibly misleading, puzzle.

35. See, for example, Edwin Mansfield, "R\&D and Innovation: Some Empirical Findings," in Griliches, ed., R\&D, Patents, and Productivity, pp. 127-48; and Griliches, "Productivity, R\&D, and Basic Research." 


\section{Comments and Discussion}

William D. Nordhaus: After almost two decades of study of the slowdown in productivity growth, economists have made remarkably little progress in understanding its causes. Among the many potential villains are such economic factors as low saving or capital formation, energy scarcity, regulation, and errors of measurement. Some analysts suggest that the productivity growth slowdown may reflect technological factors, in particular a decline in fundamental invention.

Without downplaying the importance of economic factors, I suspect that a decline in fundamental invention may play a role in the long-run decline in productivity growth. Past studies of the productivity slowdown have explained only one-third to one-half of the slowdown in the United States. There is no law of nature or economics which holds that the rate of fundamental invention should be constant. More than likely technology was largely stagnant before accelerating in the seventeenth century. Today the United States may have exhausted many of the avenues that led to rapid technological change over the last century.

Any hypothesis about technological stagnation would look for empirical evidence at the patent statistics, for these are the only solid data on invention. Griliches' paper is a thoughtful and provocative survey of the patent statistics and contributes to our understanding of the complex link between invention and economic activity. Griliches concludes that the patent data are more a reflection than a cause of the deteriorating economic environment. Although I find the argument appealing, the evidence does not in my view justify such a sweeping conclusion.

Before I discuss the relation between patents and productivity, one point must be recognized: that patents are a filtered measure of inventive output. This point is made even clearer in the Pakes and Simpson paper 
that follows. A successful patent must pass three tests: a technological test of both significance and patentability, an economic test of value to justify the cost of patenting, and a bureaucratic test of simply getting approved by the Patent Office. One of Griliches' most important findings is that the dip in patenting in the 1970s was a bureaucratic mirage. Most of the drop was simply due to a hiring freeze in the Patent Office. Surely this finding reinforces the fact that we must be careful in interpreting the time series on patents as a technological indicator.

Griliches makes a number of comments on the growing problem of American competitiveness. Is our trade balance deteriorating because our entrepreneurs are mousetrapping other firms rather than producing better mousetraps? One interesting bit of evidence is found in the data on the U.S. receipts and payments and fees associated with technology (a concept that might be called the balance of payments on disembodied technology). On that front, U.S. receipts in 1985 were four times U.S. payments, with essentially no change in that ratio over the 1972-85 period. In 1972 U.S. receipts from Japan were forty times payments, and they had fallen to eight times payments by 1985 . For new technology purchases, U.S. sales to Japan in 1985 were three times the value of sales in the other direction. These figures suggest that U.S. competitiveness is now primarily a problem of relative prices and marketing rather than one of lagging technology.

As for the relation between patenting and productivity growth, the patent data suggest that, after keeping up with real GNP from 1880 to 1930, domestic patent activity has grown little since then, and a decline in the absolute volume of patent applications occurred over the period from the mid-1960s to the early 1980 s. Superficially these data would tend to corroborate the hypothesis of technological depletion. But one needs to examine more carefully the source of the decline in patent activity before jumping to conclusions.

Discussions of the trends in patenting often try to separate supply and demand forces. Though Griliches uses this terminology, he does not lay out an explicit framework to underpin the discussion. The following model may be helpful in understanding the debate. Assume that in each of $M$ technological areas, firms invest real R\&D inputs $(R)$, which cost $C$ units, where $C=c r, c$ is the cost of research, and $r$ is the cost of capital. Of the inventions, the fraction $p$, for a total of $N$, is patented $(N=p M)$. Associated with each invention is a "size" of technological 
advance $(\Theta)$, which measures the percentage reduction in costs. If total annual sales in the relevant market is $S$, and $\Phi$ is the term for converting future annual flows into present value, then a rough estimate of the social value of the invention is $V^{S}=\Theta \Phi S$. Let $\beta$ be the degree of appropriability of the invention, so the private value of the invention is $V^{p}=\beta \Theta \Phi S$. Finally, assume that the production function for the invention is given by $\Theta=F(R)=A R^{\alpha}$, where $A$ is a shift variable for a particular field. A profit-maximizing firm will then choose the size of the invention to maximize total profits, $\pi=V^{p}-c R=\beta \Phi S A R^{\alpha}-C R$. If the resulting invention is patentable (as determined by technological trends in the patentability of invention, $\tau$ ), passes some threshold of significance (when $\Theta>\Theta^{m i n}$ ), and is worth the patenting cost (when $V^{p} \geq c^{p}$ ), then a patent results, with the total probability being $p=P\left[\tau, \Theta, \Theta^{\min }, c^{p}\right]$. This yields an equilibrium research level and patent number of $R=M(\beta \alpha A \Phi S /$ $(r)^{1 /(1-\alpha)}$ and $N=p^{M}$.

In this simple example, the research intensity and patenting depends in a complex way on what might be called supply factors, such as the technology (through factors such as $M, A, \alpha$, and $\tau$ ) and the costs of doing research or patenting inventions and legal norms (through variables $\Theta^{\text {min }}, c^{p}$, and $c$ ) as well as the cost of capital, $r$. Also, the demand factors would operate through the size of the market, $S$, and the appropriability of the invention, $\beta$.

Given the complexity of the forces affecting both research and patent behavior, a good deal of spadework would have to be done to determine the causes of declining patent intensity. A few findings in Griliches' paper are suggestive. One is that high levels of defense spending tend to lower patenting (see tables 5 and 6). These results imply that we may be forgoing much future productivity growth by spending so heavily on defense R\&D. Moreover, as Pakes and Simpson show in their paper, cost elements are extremely important in determining the number of patents in force, which suggests that patents may be declining simply because of the exploding cost of litigation.

I believe the simple model of patenting economics argues against Griliches' hypothesis that total rather than national patents count for total factor productivity (TFP). To a first approximation, a domestic patent used in domestic production lowers production costs and raises domestic TFP. An optimally exploited foreign patent used in foreign production (or licensed domestically) will not lower domestic costs 
(including royalties) or import prices for the life of the patent. Moreover, while Griliches finds that world patents grow at approximately the same rate as U.S. GNP, patents of advanced countries are surely growing more slowly than total advanced-country output.

The depletion hypothesis suggests that the cause of declining patenting is found in a downward shift in the production function for invention, say because $A$ or $\alpha$ declined over time. But at this stage there is not enough evidence to indicate whether this or another hypothesis is more likely to be correct.

Toward the end of the paper, Griliches analyzes the implication of variability in value of patents. One can go further and show that the high variance in the return on inventive activity is consistent with the variability of productivity growth. To see this, note that it is customary to fit TFP as a function of some form of technological inputs, say, as $q_{t}=a_{t}+\sigma k_{t}+(1-\sigma) l_{t}$, where $q_{t}, k_{t}$, and $l_{t}$ are logs of output, capital services, and labor services, $a_{t}$ is the level of TFP, and $\sigma$ is the capitaloutput elasticity.

Attempts to explain TFP growth on the basis of cumulative patents or R\&D have not usually been successful (as shown in figure 4). Studies by F. M. Scherer and Ariel Pakes, cited by Griliches, have found that the distribution of patent values has an extremely high variance. Scherer suggested the distribution is arc-sine (which is an infinite-variance, infinite-mean distribution). Pakes and Simpson find that half the value of patents accrues to 5 to 10 percent of all the patents.

To formalize these observations, assume that the value of patents is distributed according to a Pareto distribution. In this case TFP will follow the process, $a_{t}=\sum_{v=-\infty}^{t} \Theta_{v}$, where $\Theta_{v}$ is the value of the patent generated at time $v$ (normalized by the size of the economy).

Griliches produces an example in which, even though the value of patents has an enormously wide distribution, the aggregate variation is small. But even his example may underestimate the variability of patent value. To illustrate the effect of a Paretian distribution, assume that the number of patents is large but most of the value is concentrated in a few patents. For example, assume that 99.99 percent of patents are worth nothing, while 0.01 percent of patents are fundamental inventions-the telephone, the transistor, the airplane-whose value follows a Paretian distribution with exponent of -1.3 (a value derived from the Pakes- 
Figure 1. Actual and Simulated Productivity Growth, 1900-88

Percent

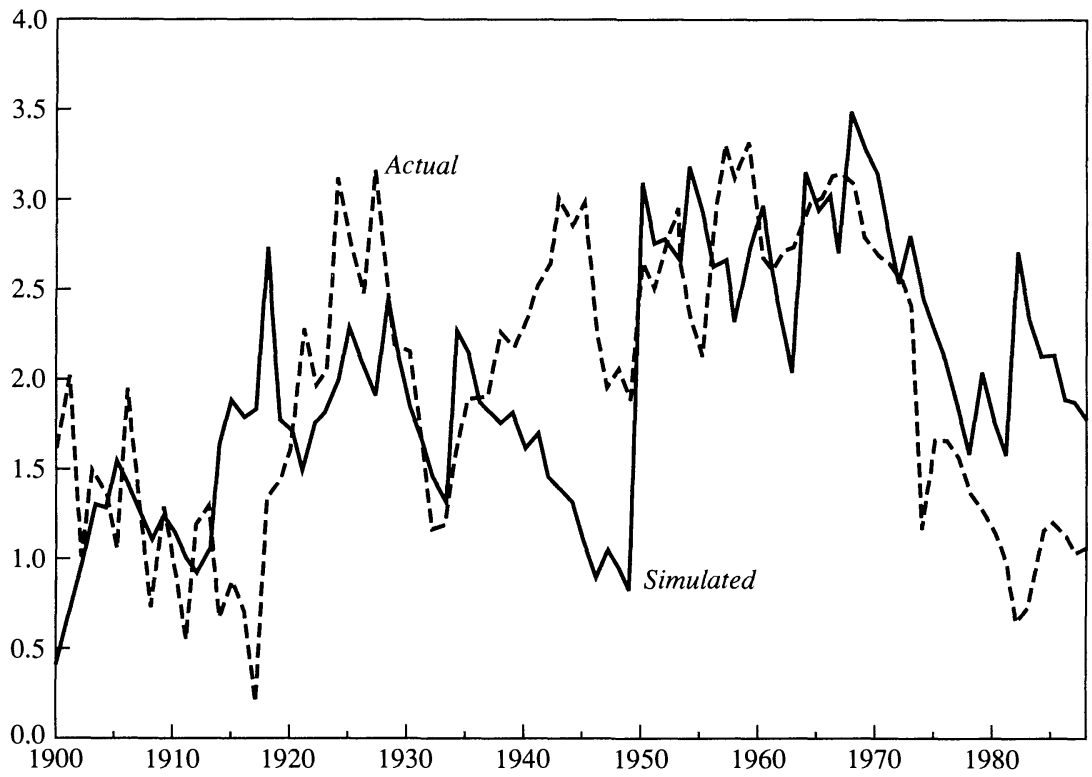

Simpson result just cited). Assume further that fundamental inventions seep into the economy very slowly, so that only 10 percent of their effect on productivity is realized in the first decade.

Technological change in such an economy is highly variable because of the extreme variability of the value of inventions. The system might go along for many years with a stagnant technology and then suddenly take off because of a few fundamental inventions. To show how such a system might behave, I have shown one simulation in figure 1 . The actual data are growth in labor productivity averaged over ten-year, overlapping intervals. The simulated values are generated according to the model described above. In the simulation the contribution of inventions is seen to vary on long time scales in a way that approximates the variability of productivity growth. In contrast to Griliches' example, this example shows how a highly skewed distribution of patents can generate a productivity series that replicates the noisiness of the actual data. 
One might react to this hypothesis by asking whether it is plausible that the returns to invention are really as variable as this example suggests. I believe so. If one thinks about the contribution to economic activity of inventions (or clusters of inventions) like the railroad, the telephone, the airplane, or the transistor-indeed, if one considers the Industrial Revolution itself-it does not seem farfetched to argue that the randomness associated with the discovery of great inventions might lie behind the long-term variability in productivity growth shown in figure 1. If that is correct, then the current productivity slowdown may well represent a lull in invention caused by the playing out of fundamental past inventions. Whether the lull is temporary or long term is momentous but unforeseeable.

F. M. Scherer: Griliches' paper, though characteristically thorough and well executed, ends with a variant on the old economist saw: if you lay all the patents in the world end-to-end, you still won't reach a conclusion on the aggregate value of any given year's cohort. This result is perhaps inevitable, given plausible changes over time in the legal environment, their impact on the propensity to patent, and the enormous variance in the value of individual patents. Nevertheless, a few observations can be added to confirm and clarify the author's findings.

For one, as Griliches recognizes, the downturn in patenting by domestic residents is not unique to the United States. From nearly complete 1963-78 series for seven major nations, I found that in all but Japan domestic application and patent issue activity peaked between 1965 and 1972-well before the first OPEC shock hit-and then declined. ${ }^{1}$ The peak years were as follows:

$\begin{array}{lcc} & \text { Applications } & \text { Issues } \\ \text { United States } & 1970 & 1971 \\ \text { France } & 1968 & 1968 \\ \text { West Germany } & 1965 & 1966 \\ \text { Sweden } & 1967 & 1970 \\ \text { Switzerland } & 1971-72 & 1966 \\ \text { United Kingdom } & 1968 & \text { n.a. }\end{array}$

Unfortunately, it is difficult to determine whether an upturn materialized in Europe during the 1980s, as it did in the United States, since many

1. F. M. Scherer, "The World Productivity Growth Slump," in Rolf Wolff, ed., Organizing Industrial Development (Berlin: Walter de Gruyter, 1986), p. 21. 
large corporations began seeking "Europatents" instead of national patents after 1978 .

One reason why patenting has risen more slowly than real R\&D might be that the inventions patented have become more complex over time. When U.S. applications are adjusted by a Patent Office index of the number of pages per printed patent, what was a trendless series for the years 1907-53 shows significant annual growth. ${ }^{2}$ I have been unable to extend the "complexity" time series beyond 1953. However, a crosssectional analysis of 15,112 patents issued to 443 Federal Trade Commission Line of Business survey corporations in 1976 and 1977 provides interesting material for the "Journal of Negative Results." Each patent was linked to the line of business in which it originated, and the average 1974 company-financed R\&D cost per received patent was computed. The average cost per patent was $\$ 588,000$. On average, the sample patents were 7.4 pages long, with a standard deviation of 8.6 pages, and embodied 9.9 separate claims of invention, with a standard deviation of 7.95 claims. To my surprise, the zero-order Pearsonian correlation between $R \& D$ costs of patents and the number of claims was -0.038 , whereas the correlation between $R \& D$ costs and pages was 0.012 . Neither correlation is statistically significant, compelling skepticism about whether complexity measures that can be extracted from patent documents are related in any simple way to the magnitude of underlying R\&D inputs.

Given the difficulties that seem inescapable with patent counts, I sought other data that might shed independent light on whether the average $R \& D$ cost per invention has been rising over time. The most promising alternative seemed to be the annual competition held since 1963 by a journal variously called Industrial Research, Industrial Research and Development, and Research and Development. Companies are invited to pay an entry fee and nominate their technological innovations. From the nominations a panel of judges chooses the hundred most significant advances of the year. Since the late 1960s the annual awards issue has included data on mean and maximum $R \& D$ costs for the winning innovations. The annual maximum $R \& D$ cost observations have

2. F. M. Scherer and others, Patents and the Corporation: A Report on Industrial Technology under Changing Public Policy, 2d ed. (Harvard University, Graduate School of Business Administration, 1959), p. 134. 
a highly skewed distribution, ranging from $\$ 4.75$ million (using the $1982=100 \mathrm{GNP}$ deflator, backward lagged three years, for price-level adjustment) to $\$ 1,114$ million. A test with the fifteen largest published yearly maximum values (plus one runner-up) yielded a close log-linear fit and a Pareto-Levy alpha coefficient of 0.60 - not much more than the value I found for the distribution of profits resulting from a sample of patented inventions. ${ }^{3}$ Asymptotically, neither the means nor the variances of such distributions are finite, which makes it difficult to draw statistical inferences about the mean R\&D cost per winning innovation across the various annual cohorts. (Measured in 1982 dollars, the annual means ranged from $\$ 809,000$ to $\$ 14.1$ million.) The best that could be done with the published data was to remove from each year's cohort the most costly innovation, recomputing the mean without that observation. For the sixteen observations on which that was possible, R\&D cost per innovation increased at an average annual rate of 0.97 percent, but the time trend was not statistically significant. The implication is that real costs per invention have not been rising over the period of time when U.S. patenting fell. But the data are quite limited. More interesting results might emerge if the full data set, rather than mean and maximum annual observations only, could be obtained from the publisher.

Against these essentially negative results, one must juxtapose the even more fragmentary evidence we have on very long-run trends in technological effort, patenting, and productivity. Derek de Solla Price has shown that since 1750 the number of scientists and engineers has been growing at an annual rate of roughly 4.3 percent, and the number of scientific journals rather steadily at 4.5 percent. ${ }^{4}$ Meanwhile the number of U.S. patents rose only 1.34 percent annually over the last century (and even more slowly if only patents issued to U.S. residents are considered). Since the time of the Industrial Revolution, labor productivity growth has averaged 1 to 2 percent a year in the leading industrialized nations. These relationships, like Griliches' figure 6, suggest that, because of some imperfectly understood diminishing returns phenomenon, maintaining a given rate of improvement in technol-

3. F. M. Scherer, "Firm Size, Market Structure, Opportunity, and the Output of Patented Inventions,' American Economic Review, vol. 55 (December 1965), p. 1098.

4. Derek J. de Solla Price, Little Science, Big Science (Columbia University Press, 1963), p. 8 . 
ogy and hence productivity may require a substantially more rapid rate of increase in the inputs devoted to technology-advancing activities.

Much more work is needed to sharpen our understanding of these important relationships. I hesitate to repeat Albert Stafford's error and conclude that no further progress is possible with patent data, given the substantial strides already achieved by Griliches and his team. But to move forward, researchers probably must undertake data set links spanning longer periods of time-for example, by using the R\&D laboratory employment census data compiled by Mowery. ${ }^{5}$ Economic historians can also contribute. Pratten has shown that labor productivity grew at an average annual rate of 2.6 percent over the two centuries after Adam Smith's discussion of how far the pinmaking art had been carried as of $1776 .{ }^{6}$ Careful analyses of what had to be done to sustain a high rate of progress in pinmaking and other fields with relatively stable product designs, and how among other things the technical changes were tracked by patent grants, might provide valuable insight into the underlying phenomena.

I close with a quibble. In the last section of his paper, Griliches notes that at least half of the observed growth in total factor productivity can be attributed to increases in labor quality, economies of scale, and reallocations of capital, as distinguished from advances in knowledge associated with patentable new technology. It is far from clear that one can disentangle these determinants so cleanly. Most process scaleups require invention and technical development. Upgrading the labor force through enhanced education is crucial to achieving new technical advances and operating the more complex equipment they make available. Some of the most important productivity-increasing resource reallocations-for example, from farming to manufacturing and more recently from manufacturing to services-would have been impossible without relatively rapid technical progress in the fields from which resources were diverted. Thus I believe Griliches underestimates the facilitating role that technical progress, narrowly construed, has played and will continue to play.

5. David C. Mowery, "Industrial Research and Firm Size, Survival, and Growth in American Manufacturing, 1921-1946,', Journal of Economic History, vol. 43 (December 1983), pp. 953-79.

6. Clifford F. Pratten, "The Manufacture of Pins," Journal of Economic Literature, vol. 18 (March 1980), pp. 93-96. 


\section{General Discussion}

Participants offered several reasons why the slowdown in patenting might not necessarily lead to a slowdown in productivity growth. Richard Gilbert, in particular, suggested three such reasons. The first relates to findings from the Yale survey research on $R \& D$ showing that some corporations use patents as a way of monitoring and measuring the performance of their scientists or other researchers. If the "monitoring technology" has changed in some way, patents might not be as useful for that purpose, and this could lead to a reduction in the rate at which new patents are issued that is not related to the rate at which new innovations are being produced.

A second reason is that other means of appropriation of the gains from innovation, such as secrecy or lead times, may have become more important. And a third reason is that a large part of innovative effort in the 1970s may have been devoted to improving input substitutability in response to the large shifts in relative prices that occurred during that decade. The resulting improvement in the ability of producers to move along the production possibility frontier might not show up as an increase in total factor productivity, and might not present as many patenting opportunities, but should be regarded as a technological advance nonetheless.

Richard Levin suggested that the rise in the proportion of Japanese to American patents being issued might be an artifact of the Japanese tendency to file single-claim patents. Patent filings by U.S. citizens, by contrast, make an average of about ten claims per filing. But Suzanne Scotchmer noted that Japanese patents are cited much more frequently than U.S. patents, which suggests that they may tend to make a larger contribution to the body of technological knowledge.

Martin Baily wondered whether Mike Scherer's emphasis on the skewness of the distribution of patent values could be misleading, since many small innovations have a large effect on productivity. Scherer agreed, citing Samuel Hollander's study showing that something like half the productivity improvements in Du Pont rayon plants could be attributed to unpatented, shop-floor improvements.

Explaining his doubts about a causal relationship running from the slowdown in patenting to the decline in productivity growth, Griliches 
noted that the diffusion time for most major innovations is very long. Most patents in a new area of innovation are taken out very early in the process, Griliches said. "They are taken out almost as fast as you get the first idea," but then it takes a long time for these ideas to be put into effect in enough places to have a significant impact on productivity in the alleged time frame. 